\title{
Oxygen isotopic composition of nitrate and nitrite produced by nitrifying cocultures and natural marine assemblages
}

\author{
Carolyn Buchwald, a,* Alyson E. Santoro, ${ }^{\mathrm{b}, 1}$ Matthew R. McIlvin, ${ }^{\mathrm{b}}$ and Karen L. Casciotti b,2
}

a Massachusetts Institute of Technology/ Woods Hole Oceanographic Institution Joint Program in Chemical Oceanography, Woods Hole Oceanographic Institution, Woods Hole, Massachusetts

b Marine Chemistry and Geochemistry Department, Woods Hole Oceanographic Institution, Woods Hole, Massachusetts

\begin{abstract}
The $\delta^{18} \mathrm{O}$ value of nitrate produced during nitrification $\left(\delta^{18} \mathrm{O}_{\mathrm{NO}_{3}, \text { nit }}\right)$ was measured in experiments designed to mimic oceanic conditions, involving cocultures of ammonia-oxidizing bacteria or ammonia-oxidizing archaea and nitrite-oxidizing bacteria, as well as natural marine assemblages. The estimates of $\delta^{18} \mathrm{O}_{\mathrm{NO}_{3} \text {, nit }}$ ranged from $-1.5 \%$ $\pm 0.1 \%$ to $+1.3 \%$ o $\pm 1.4 \%$ at $\delta^{18} \mathrm{O}$ values of water $\left(\mathrm{H}_{2} \mathrm{O}\right)$ and dissolved oxygen $\left(\mathrm{O}_{2}\right)$ of $0 \%$ and $24.2 \%$ vs. Vienna Standard Mean Ocean Water, respectively. Additions of ${ }^{18} \mathrm{O}$-enriched $\mathrm{H}_{2} \mathrm{O}$ allowed us to evaluate the effects of

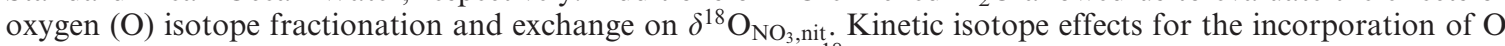

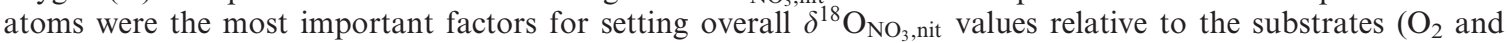
$\left.\mathrm{H}_{2} \mathrm{O}\right)$. These isotope effects ranged from $+10 \%$ to $+22 \%$ for ammonia oxidation $\left(\mathrm{O}_{2}\right.$ plus $\mathrm{H}_{2} \mathrm{O}$ incorporation $)$ and from $+1 \%$ to $+27 \%$ for incorporation of $\mathrm{H}_{2} \mathrm{O}$ during nitrite oxidation. $\delta^{18} \mathrm{O}_{\mathrm{NO}_{3}}$, nit values were also affected by the amount and duration of nitrite accumulation, which permitted abiotic $\mathrm{O}$ atom exchange between nitrite and $\mathrm{H}_{2} \mathrm{O}$. Coculture incubations where ammonia oxidation and nitrite oxidation were tightly coupled showed low levels of nitrite accumulation and exchange $(3 \% \pm 4 \%)$. These experiments had $\delta^{18} \mathrm{O}_{\mathrm{NO}_{3} \text {, nit }}$ values of $-1.5 \%$ to $+0.7 \%$. Field experiments had greater accumulation of nitrite and a higher amount of exchange (22\% to $100 \%)$, yielding

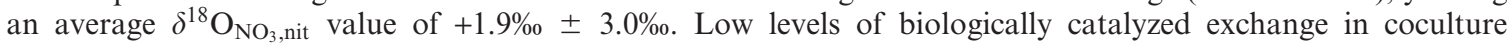
experiments may be representative of nitrification in much of the ocean where nitrite accumulation is low. Abiotic oxygen isotope exchange may be important where nitrite does accumulate, such as oceanic primary and secondary nitrite maxima.
\end{abstract}

A supply of bioavailable nitrogen $(\mathrm{N})$ in the form of nitrate $\left(\mathrm{NO}_{3}^{-}\right)$is important for primary production and carbon export to the deep ocean (Eppley and Peterson 1979), and understanding the oceanic nitrate budget is essential to understanding past, present, and future ocean productivity (Codispoti et al. 2001). Stoichiometry-based geochemical estimates of the oceanic nitrate budget often return a nearly balanced budget, albeit with large uncertainties (Gruber and Sarmiento 1997; Gruber and Galloway 2008). Construction of an oceanic nitrate budget based on $\delta^{15} \mathrm{~N}\left(\delta^{15} \mathrm{~N}(\% 0)=\left({ }^{15} \mathrm{~N} / 14 \mathrm{~N}_{\text {sample }} \div{ }^{15} \mathrm{~N} /\right.\right.$ $\left.\left.{ }^{14} \mathrm{~N}_{\text {standard }}-1\right) \times 1000\right)$ leads to a budget with sinks (burial, denitrification, and anammox) far outweighing the sources ( $\mathrm{N}$ fixation, continental runoff, and atmospheric deposition; Brandes and Devol 2002; Deutsch et al. 2004). Because sedimentary records are inconsistent with such an imbalance (Deutsch et al. 2004; Altabet 2007), this prediction demonstrates gaps in our understanding of the oceanic nitrogen budget and its isotopic systematics.

Since the development of the denitrifier method for isotopic analysis of nitrate (Sigman et al. 2001; Casciotti et al. 2002), many studies have focused on the use of

\section{*Corresponding author: cbuchwald@whoi.edu}

\section{Present addresses:}

${ }^{1}$ Horn Point Laboratory, University of Maryland Center for Environmental Science, Cambridge, Maryland

${ }^{2}$ Department of Environmental Earth System Science, Stanford University, Stanford, California coupled $\mathrm{N}$ and oxygen (O) isotopes in nitrate to help constrain oceanic $\mathrm{N}$ cycling and the nitrate budget. The value of the coupled isotope approach is that the $\delta^{18} \mathrm{O}\left(\delta^{18} \mathrm{O}\right.$ $\left.(\%)=\left({ }^{18} \mathrm{O} /{ }^{16} \mathrm{O}_{\text {sample }} \div{ }^{18} \mathrm{O} /{ }^{16} \mathrm{O}_{\text {standard }}-1\right) \times 1000\right)$ value of nitrate $\left(\delta^{18} \mathrm{O}_{\mathrm{NO}_{3}}\right)$ is set by a different set of processes than its $\delta^{15} \mathrm{~N}$ value $\left(\delta^{15} \mathrm{~N}_{\mathrm{NO}_{3}}\right.$ ) (Sigman et al. 2005). Water column denitrification, sedimentary denitrification, and nitrate assimilation are processes that fractionate $\mathrm{N}$ and $\mathrm{O}$ isotopes equally (Granger et al. 2004; Granger et al. 2008), but nitrate regeneration can decouple the $\mathrm{N}$ and $\mathrm{O}$ isotopes in nitrate (Sigman et al. 2009). During nitrate uptake and regeneration, $\mathrm{N}$ atoms are recycled between fixed $\mathrm{N}$ pools, while $\mathrm{O}$ atoms are removed, then replaced by the nitrification process. Therefore, while the $\mathrm{N}$ isotope budget is sensitive only to input (nitrogen fixation) and output (denitrification) processes, the $\mathrm{O}$ isotopes in nitrate are sensitive to internal cycling (assimilation, regeneration, nitrification) as well. To determine the relative amounts of water column denitrification and sedimentary denitrification using the $\delta^{18} \mathrm{O}$ values of deep ocean nitrate, it is necessary to account for the nitrate $\delta^{18} \mathrm{O}$ variations caused by internal cycling, and a key parameter here is the $\delta^{18} \mathrm{O}$ value of nitrate produced by nitrification $\left(\delta^{18} \mathrm{O}_{\mathrm{NO}_{3}, \text { nit }}\right)$.

The microbial process of nitrification is carried out in two main steps: ammonia oxidation to nitrite, followed by nitrite oxidation to nitrate (Fig. 1). $\delta^{18} \mathrm{O}_{\mathrm{NO}_{3} \text {, nit }}$ is determined by the $\delta^{18} \mathrm{O}$ values of $\mathrm{O}$ atom sources $\left(\mathrm{O}_{2}\right.$ and $\mathrm{H}_{2} \mathrm{O}$; Andersson and Hooper 1983; Kumar et al. 1983), the amount of $\mathrm{O}$ atom exchange between nitrite and $\mathrm{H}_{2} \mathrm{O}(x)$, and the isotope effects involved with $\mathrm{O}$ atom incorporation 

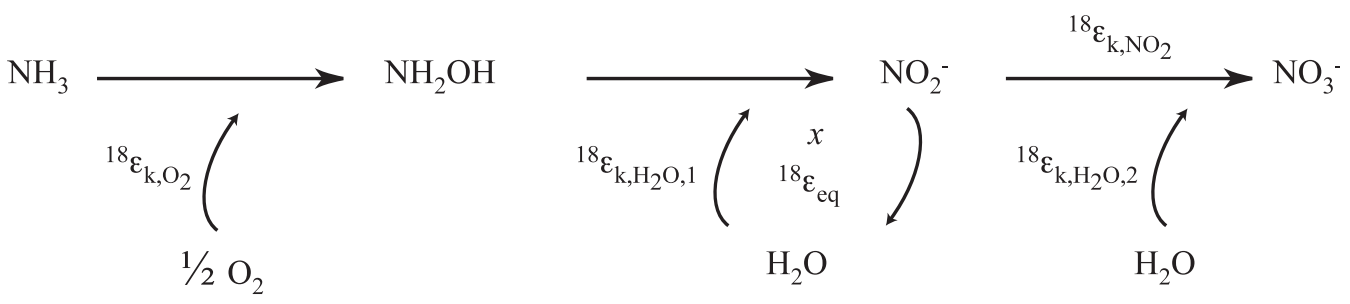

Fig. 1. Nitrification pathway showing oxygen atom sources with isotope effects for incorporation and exchange.

$\left({ }^{18} \varepsilon_{\mathrm{k}, \mathrm{O}_{2}},{ }^{18} \varepsilon_{\mathrm{k}, \mathrm{H}_{2} \mathrm{O}, 1},{ }^{18} \varepsilon_{\mathrm{k}, \mathrm{H}_{2} \mathrm{O}, 2}\right)$ and exchange $\left({ }^{18} \varepsilon_{\mathrm{eq}} ;\right.$ Casciotti et al. 2010; Buchwald and Casciotti 2010). In the deep ocean, $\delta^{18} \mathrm{O}_{\mathrm{H}_{2} \mathrm{O}}$ values vary little $(-0.5 \%$ to $+0.5 \%$ vs. Vienna Standard Mean Ocean Water [VSMOW]; Epstein and Mayeda 1953), while $\delta^{18} \mathrm{O}_{\mathrm{O}_{2}}$ values range from $+24.2 \%$ to near $+36 \%$ vs. VSMOW (Bender 1990). The $\delta^{18} \mathrm{O}$ value of deep ocean nitrate, which sets an upper limit on $\delta^{18} \mathrm{O}_{\mathrm{NO}_{3} \text {,nit }}$, is less than $+2.5 \%$ vs. VSMOW on average and varies little $\left( \pm 1.0 \%\right.$ ) relative to variations in $\delta^{18} \mathrm{O}_{\mathrm{O}_{2}}$ in the ocean interior (Casciotti et al. 2002; Sigman et al. 2009). These features of oceanic $\delta^{18} \mathrm{O}_{\mathrm{NO}_{3}}$ (low $\delta^{18} \mathrm{O}$ value and little variation in intermediate and deep water) would seem to argue against retention of $\mathrm{O}$ from $\mathrm{O}_{2}$ introduced during ammonia oxidation.

Early studies of ammonia oxidation suggest that a large amount of oxygen isotope exchange may occur between nitrite and $\mathrm{H}_{2} \mathrm{O}$, consistent with a loss of the primary $\mathrm{O}_{2}$ signal (Dua et al. 1979; Andersson et al. 1982). Therefore, efforts to use $\delta^{18} \mathrm{O}_{\mathrm{NO}_{3}}$ values as constraints on oceanic nitrogen cycling have generally assumed that $\delta^{18} \mathrm{O}_{\mathrm{NO}_{3} \text {,nit }}$ is equal to that of seawater (near $0 \%$ vs. VSMOW) due to full equilibration of nitrite with $\mathrm{H}_{2} \mathrm{O}$ during ammonia oxidation (Casciotti and McIlvin 2007; DiFiore et al. 2009; Sigman et al. 2009). However, equilibration between nitrite and $\mathrm{H}_{2} \mathrm{O}$ has recently been shown to involve a temperaturedependent equilibrium isotope effect between nitrite and $\mathrm{H}_{2} \mathrm{O}$ of $+11 \%$ o to $+15 \%$ o (Casciotti et al. 2007; C. Buchwald and K. L. Casciotti unpubl.). Full expression of the equilibrium isotope effect during nitrification, or abiotic exchange thereafter, should lead to production of nitrite with $\delta^{18} \mathrm{O}$ values of $+11 \%$ to $+15 \%$ vs. VSMOW. While incorporation of $\mathrm{H}_{2} \mathrm{O}$ during nitrite oxidation can lower the $\delta^{18} \mathrm{O}$ value of the final nitrate produced, in order to achieve $\delta^{18} \mathrm{O}_{\mathrm{NO}_{3}}$ source values near $0 \%, \mathrm{H}_{2} \mathrm{O}$ incorporation would need to occur with an isotope effect $\left({ }^{18} \varepsilon_{\mathrm{k}, \mathrm{H}_{2} \mathrm{O}, 2}\right)$ of approximately $28 \%$, which is larger than has been observed to date (12.8\%o to $18.2 \%$; Buchwald and Casciotti 2010).

Some recent experiments accounting for abiotic exchange have shown that ammonia oxidation is likely to retain a significant fraction of the $\mathrm{O}$ atoms incorporated from $\mathrm{O}_{2}$ (Casciotti et al. 2010). These experiments also demonstrated that isotopic fractionation associated with $\mathrm{O}$ atom incorporation during ammonia oxidation (Casciotti et al. 2010) and nitrite oxidation (Buchwald and Casciotti 2010) provides an additional mechanism for achieving low $\delta^{18} \mathrm{O}_{\mathrm{NO}_{3} \text {,nit }}$ values with incomplete $\mathrm{O}$ atom exchange. Putting together results from laboratory monoculture experiments, Buchwald and Casciotti (2010) predicted $\delta^{18} \mathrm{O}_{\mathrm{NO}_{3} \text {,nit }}=-8.3 \%$ to $-0.7 \%$ in seawater with $\delta^{18} \mathrm{O}_{\mathrm{H}_{2} \mathrm{O}}=0 \%$ and $\delta^{18} \mathrm{O}_{\mathrm{O}_{2}}=$ $+24.2 \%$. The large range in predicted $\delta^{18} \mathrm{O}_{\mathrm{NO}_{3}, \text { nit }}$ occurred as a result of variations in the amount of exchange and kinetic isotope fractionation expressed during ammonia oxidation and nitrite oxidation among the different bacterial species studied. While these values span the range required to explain a deep ocean $\delta^{18} \mathrm{O}_{\mathrm{NO}_{3}}$ value of $+2.5 \%$, they lack sufficient predictive power for use in interpretation or modeling of oceanic nitrate isotope distributions. Determination of the oxygen isotopic exchange and fractionation during nitrification under natural environmental conditions is therefore critical to predicting the source of $\delta^{18} \mathrm{O}$ in nitrate and its variation with seawater $\delta^{18} \mathrm{O}_{\mathrm{H}_{2} \mathrm{O}}$ and $\delta^{18} \mathrm{O}_{\mathrm{O}_{2}}$.

The goal of this study was to determine the $\delta^{18} \mathrm{O}$ value of nitrate that is produced during nitrification under more natural conditions than the previous experiments, using mixed communities where ammonia oxidation and nitrite oxidation are tightly coupled. Laboratory cocultures of ammonia-oxidizing bacteria (AOB) or archaea (AOA) with nitrite-oxidizing bacteria (NOB) and natural microbial assemblages from temperate and tropical ocean sites were used to examine the importance of nitrite accumulation (magnitude and duration) and isotopic exchange on the resulting $\delta^{18} \mathrm{O}_{\mathrm{NO}_{3}}$ values. This information is important for evaluating the factors controlling the $\delta^{18} \mathrm{O}$ value of newly produced nitrate and interpreting $\delta^{18} \mathrm{O}_{\mathrm{NO}_{3}}$ in the ocean.

\section{Methods}

Culture maintenance-Three cultures were used in paired laboratory coculture experiments: Nitrosomonas sp. C-113a, a marine AOB isolated from the Red Sea (Ward and Carlucci 1985); CN25, an AOA enrichment from the California Current (Santoro and Casciotti 2011); and Nitrococcus mobilis, a marine NOB isolated from the Galapagos Islands (Watson and Waterbury 1971). Maintenance batch cultures of C-113a were grown in Watson medium (Watson 1965) with $10 \mathrm{mmol} \mathrm{L}-1 \mathrm{NH}_{4}^{+}$. The ammonia-oxidizing archaeal enrichment was grown in oligotrophic North Pacific medium consisting of $0.2-\mu \mathrm{m}$-filtered North Pacific surface seawater amended with $10-100 \mu \mathrm{mol} \mathrm{L}^{-1} \mathrm{NH}_{4} \mathrm{Cl}, 1 \mathrm{~mL} \mathrm{~L}^{-1}$ chelated trace elements solution (Balch et al. 1979), and $2 \mathrm{mg} \mathrm{L}^{-1}$ $\mathrm{KH}_{2} \mathrm{PO}_{4}$ (Santoro and Casciotti 2011). The nitrite-oxidizing species, $N$. mobilis, was grown in batch culture in medium with $75 \%$ artificial seawater and $25 \%$ distilled water amended with $400 \mu \mathrm{mol} \mathrm{L}-1 \mathrm{MgSO}_{4}, 30 \mu \mathrm{mol} \mathrm{L}-1 \mathrm{CaCl}_{2}, 5 \mu \mathrm{mol} \mathrm{L}-1$ $\mathrm{K}_{2} \mathrm{HPO}_{4}, 2.3 \mu \mathrm{mol} \mathrm{L} \mathrm{L}^{-1} \mathrm{Fe}(\mathrm{III})$-ethylenediaminetetraacetic acid ("Geigy iron"), $0.1 \mu \mathrm{mol} \mathrm{L}-1 \mathrm{Na}_{2} \mathrm{MoO}_{4}, 0.25 \mu \mathrm{mol} \mathrm{L}-1$ $\mathrm{MnCl}_{2}, 0.002 \mu \mathrm{mol} \mathrm{L}-1 \mathrm{CoCl}_{2}, 0.08 \mu \mathrm{mol} \mathrm{L}^{-1} \mathrm{ZnSO}_{4}$, and $10 \mathrm{mmol} \mathrm{L}-1 \mathrm{NO}_{2}^{-}$(Watson and Waterbury 1971). 
Coculture experimental conditions-Two types of coculture experiments were conducted in the laboratory: (1) cocultures of C-113a and N. mobilis and (2) cocultures of an ammonia-oxidizing archaeal enrichment (CN25) and $N$. mobilis (Table 1; Fig. 2). Incubations of C-113a and $N$. mobilis were conducted in Watson medium made with artificial seawater and an initial ammonium concentration of $50 \mu \mathrm{mol} \mathrm{L}^{-1}$. To ensure consistent behavior with previous experiments, monoculture incubations of each bacterium were run in parallel. Finally, abiotic equilibration of nitrite $\mathrm{O}$ atoms with $\mathrm{H}_{2} \mathrm{O}$ was tracked through incubation of abiotic controls (uninoculated sterile media) with $50 \mu \mathrm{mol} \mathrm{L}-1$ nitrite added.

For each coculture experiment (CCE), media with four different $\delta^{18} \mathrm{O}_{\mathrm{H}_{2} \mathrm{O}}$ values (between $-5 \%$ and $+216 \%$ ) were prepared in replicate $200-\mathrm{mL}$ volumes with additions of $0,2.5,5$, and $10 \mathrm{~mL}$ of $18 \mathrm{O}$-enriched $\left(\delta^{18} \mathrm{O}_{\mathrm{H}_{2} \mathrm{O}}=+5000 \%\right)$ water. Cells for each $\mathrm{CCE}$ were harvested from maintenance cultures by filtration $(200 \mathrm{~mL}$ for $\mathrm{AOB}$ and $10 \mathrm{~mL}$ for NOB, to achieve similar cell densities). Filtered cells were washed and resuspended in $8 \mathrm{~mL}$ of filtered artificial seawater, then added to the incubation bottles $(1 \mathrm{~mL}$ per bottle). In CCE 4, three parallel treatments were carried out with $\mathrm{AOB}$ and three different volumes of NOB inoculum ( $1 \mathrm{~mL}, 100 \mu \mathrm{L}$, or $10 \mu \mathrm{L}$ concentrated cell suspension), which yielded approximately $1.7 \times 10^{4}, 1.7 \times 10^{3}, 1.7 \times$ $10^{2}$ cells $\mathrm{mL}^{-1}$, respectively. Each inoculum level was incubated with four different $\delta^{18} \mathrm{O}_{\mathrm{H}_{2} \mathrm{O}}$ media, as described above. In CCEs 1, 2, and 4, subsamples of $15 \mathrm{~mL}$ were collected throughout the incubations to monitor changes in the concentrations of ammonia, nitrite, and nitrate over time (3-16 d). In CCE 3 only initial and final (22 d) time points were collected.

The incubations involving AOA enrichments were initiated by splitting a 1-liter batch culture among eight different bottles, rather than filtering and resuspending the cells, which has a deleterious effect on AOA growth. Four of the eight bottles were inoculated with $\mathrm{NOB}$, and four were incubated without NOB. For the incubations including NOB, $10 \mathrm{~mL}$ of $N$. mobilis cells were filtered, washed, and resuspended in $4 \mathrm{~mL}$ of filtered seawater, then injected into the four coculture bottles ( $1 \mathrm{~mL}$ per bottle). Both sets of four bottles were comprised of four media $\delta^{18} \mathrm{O}_{\mathrm{H}_{2} \mathrm{O}}$ values, achieved by additions of ${ }^{18} \mathrm{O}$-enriched water $\left(\delta^{18} \mathrm{O}_{\mathrm{H}_{2} \mathrm{O}}=\right.$ $+5000 \%$ ) as described above. Because the AOA cultures were maintained in their spent medium, each experiment began with preexisting nitrite and ammonium. At the beginning of the coculture experiments, ammonium was amended to a total of $100 \mu \mathrm{mol} \mathrm{L}{ }^{-1}$ in each bottle. Samples were collected initially and periodically over the course of 23-59 d to monitor changes in the concentrations and isotopic composition of nitrite and nitrate over time. Bottles of sterile AOA medium with varying $\delta^{18} \mathrm{O}_{\mathrm{H}_{2} \mathrm{O}}$ additions were spiked with $100 \mu \mathrm{mol} \mathrm{L}-1$ ammonium and $100 \mu \mathrm{mol} \mathrm{L}-1$ nitrite and sampled in parallel to assess abiotic exchange rates in this medium.

Natural community experiments-Three field experiments (FEs) were conducted using surface water collected from Vineyard Sound in Woods Hole, Massachusetts in
September 2009, October 2009, and March 2010. Nine field experiments were conducted on a cruise to the Costa Rica Upwelling Dome (CRD) in July 2010 (MV1008), only three of which were successful and will be discussed here. Finally, two field experiments were conducted in the Eastern Tropical South Pacific (ETSP) in March-April 2011 (MV1104).

Vineyard Sound surface water was bucket sampled into 4-liter amber bottles, which were rinsed with sample water prior to filling and brought back to the laboratory to initiate experiments. In each of the first two Vineyard Sound experiments (FEs 7 and 8), three large (1 liter) bottles of natural seawater were incubated with $50 \mu \mathrm{mol} \mathrm{L} \mathrm{L}^{-1} \mathrm{am}-$ monium but no ${ }^{18} \mathrm{O}$-enriched water, and 12 smaller $(160 \mathrm{~mL})$ serum bottles were incubated with different amounts of ${ }^{18} \mathrm{O}$-enriched water in addition to the added ammonium. Nitrification was never detected in the 160$\mathrm{mL}$ bottles, and they will not be discussed further. In FE 9 , $500 \mathrm{~mL}$ of water was incubated in four different Erlenmeyer flasks that each received $50 \mu \mathrm{mol} \mathrm{L}^{-1}$ ammonium and a different amount $(0,2.5,5$, or $10 \mathrm{~mL})$ of ${ }^{18} \mathrm{O}$ enriched water $\left(\delta^{18} \mathrm{O}_{\mathrm{H}_{2} \mathrm{O}}=+5000 \%\right)$. In FE $9,500 \mathrm{~mL}$ of sea water was also $0.22-\mu \mathrm{m}$ filtered and then incubated with nitrite in a sterile flask with $10 \mathrm{~mL}$ of ${ }^{18} \mathrm{O}$-enriched water to monitor abiotic exchange. All experiments were initiated by the addition of ammonium and then monitored and subsampled during conversion to nitrite and nitrate over a period of 50 to $84 \mathrm{~d}$.

Successful incubations from the CRD were set up using water from the surface $(2 \mathrm{~m})$ and from the primary nitrite maximum $(20 \mathrm{~m})$ at one station $\left(10^{\circ} 8^{\prime} \mathrm{N}, 93^{\circ} 0^{\prime} \mathrm{W}\right.$, Sta. 3) and the primary nitrite maximum $(30 \mathrm{~m})$ at another station $\left(8^{\circ} 59^{\prime} \mathrm{N}, 90^{\circ} 30^{\prime} \mathrm{W}\right.$, Sta. 2$)$. At each station and depth, whole water was collected from 100-liter Niskin bottles and split among eight $500-\mathrm{mL}$ acid-cleaned clear polycarbonate bottles (to have duplicate incubations at each $\delta^{18} \mathrm{O}_{\mathrm{H}_{2} \mathrm{O}}$ value). Four bottles were also set up as abiotic controls by $0.2-\mu \mathrm{m}$ filtering water from the same depths into acidcleaned polycarbonate bottles. Each experiment received the ${ }^{18} \mathrm{O}$-enriched $\mathrm{H}_{2} \mathrm{O}$ spikes and a starting ammonium concentration of $50 \mu \mathrm{mol} \mathrm{L}^{-1}$ and was subsampled over a period of 67,113 , or $98 \mathrm{~d}$.

Nearly identical incubations were set up using water from the surface $(2 \mathrm{~m})$ and from just below the primary nitrite maximum $(111 \mathrm{~m})$ in the ETSP $\left(10^{\circ} 0^{\prime} \mathrm{S}, 89^{\circ} 59^{\prime} \mathrm{W}\right)$. The main difference was that at each depth, two sets of eight acid-cleaned polycarbonate bottles were set up with lower starting ammonium concentrations (one set at $1 \mu \mathrm{mol} \mathrm{L}-1$ and the second set at $5 \mu \mathrm{mol} \mathrm{L}{ }^{-1}$ ). Bottles were subsampled periodically to check nitrite concentrations but were only sampled for $\delta^{18} \mathrm{O}_{\mathrm{NO}_{3}}$ measurements initially and after full conversion of ammonium to nitrate $(180 \mathrm{~d})$.

Concentration analysis-Ammonium concentrations were measured using the indophenol blue assay (Solorzano 1969). Nitrite concentrations were measured using the Greiss-Ilosvay colorimetric method (Strickland and Parsons 1972). Ammonium and nitrite samples were measured at wavelengths of 640 and $543 \mathrm{~nm}$, respectively, on an 
Table 1. Summary of experiments.

\begin{tabular}{|c|c|c|c|c|c|c|c|}
\hline Expt & $\begin{array}{l}\text { Organisms or } \\
\text { field location } \\
\text { and depth }\end{array}$ & $\begin{array}{l}\text { Duration of } \\
\text { incubation }(d)\end{array}$ & $\begin{array}{l}\text { Days of nitrite } \\
\text { accumulation }\end{array}$ & $\begin{array}{l}\text { Maximum accu- } \\
\text { mulated nitrite } \\
(\mu \mathrm{mol} \mathrm{L}-1)\end{array}$ & $\begin{array}{c}\Delta[\text { Nitrate }] \div \\
\Delta[\text { Ammonium }]\end{array}$ & $\begin{array}{c}\delta^{18} \mathrm{O}_{\mathrm{H}_{2} \mathrm{O}}(\% \text { vs. } \\
\text { VSMOW)* }\end{array}$ & $\begin{array}{c}\delta^{18} \mathrm{O}_{\mathrm{NO}_{3}, \text { nit }}(\% \text { o } \\
\text { vs. VSMOW } \dagger\end{array}$ \\
\hline \multirow[t]{8}{*}{1} & C-113a, & 3 & 2 & 4.0 & 0.91 & -5.4 & -5.2 \\
\hline & N. mobilis & & & 4.0 & 0.90 & -5.4 & -5.3 \\
\hline & & & & 4.0 & 0.89 & 17.7 & 10.8 \\
\hline & & & & 4.0 & 0.90 & 17.7 & 10.8 \\
\hline & & & & 4.0 & 0.90 & 40.5 & 26.6 \\
\hline & & & & 4.0 & 0.88 & 40.7 & 26.9 \\
\hline & & & & 4.0 & 0.90 & 85.6 & 58.1 \\
\hline & & & & 4.0 & 0.92 & 85.7 & 58 \\
\hline \multirow[t]{4}{*}{2} & C-113a, & 5.4 & 3.5 & 1.1 & 0.98 & -5.8 & -5.7 \\
\hline & N. mobilis & & & 1.1 & 1.05 & -5.8 & -5.2 \\
\hline & & & & 1.1 & 0.98 & 85.4 & 56.7 \\
\hline & & & & 1.1 & 1.01 & 85.4 & 56.9 \\
\hline \multirow[t]{8}{*}{3} & C-113a, & nd & nd & nd & 0.98 & -5.2 & -4.3 \\
\hline & N. mobilis & & & nd & 1.04 & -5.2 & -4.4 \\
\hline & & & & nd & 0.99 & 48.8 & 30.8 \\
\hline & & & & nd & 0.96 & 48.8 & 30.9 \\
\hline & & & & nd & 0.97 & 106.1 & 68.2 \\
\hline & & & & nd & 0.99 & 106.1 & 68.0 \\
\hline & & & & nd & 1.01 & 216.0 & 137.3 \\
\hline & & & & nd & 1.07 & 216.0 & 140.1 \\
\hline \multirow[t]{4}{*}{$4 a$} & C-113a, & 3.25 & 3 & 1.4 & 1.04 & -5.3 & -5.3 \\
\hline & N. mobilis & & & 1.4 & 1.18 & 16.9 & 10.9 \\
\hline & & & & 1.3 & 1.15 & 39.6 & 25.4 \\
\hline & & & & 1.2 & 1.09 & 82.1 & 54.8 \\
\hline \multirow[t]{4}{*}{$4 b$} & C-113a, & 7.25 & 7 & 25.5 & 1.18 & -6.9 & -4.0 \\
\hline & N. mobilis & & & 25.2 & 0.96 & 17.3 & 12.2 \\
\hline & & & & 24.9 & 0.99 & 39.5 & 28.1 \\
\hline & & & & 24.2 & 1.18 & 81.2 & 58.6 \\
\hline \multirow[t]{4}{*}{$4 c$} & C-113a, & 16.25 & 16 & 45.1 & 1.16 & -5.2 & -3.7 \\
\hline & N. mobilis & & & 45.5 & 0.99 & 17.1 & 12.9 \\
\hline & & & & 45.8 & 1.01 & 39.4 & 30.3 \\
\hline & & & & 45.1 & 0.97 & 81.1 & 61.3 \\
\hline \multirow[t]{4}{*}{5} & AOA enrichment, & 23 & 15 & 1.7 & 0.79 & 0.2 & -1.4 \\
\hline & N. mobilis & & & 1.9 & 1.04 & 19.6 & 11.7 \\
\hline & & & & 1.1 & 1.06 & 37.2 & 23.8 \\
\hline & & & & 0.9 & 0.95 & 75.5 & 50.4 \\
\hline \multirow[t]{4}{*}{6} & AOA enrichment, & 59 & nd & 1.7 & 1.09 & -0.4 & 0.4 \\
\hline & N. mobilis & & & 1.9 & 1.00 & 20.1 & 14.1 \\
\hline & & & & 1.1 & 1.15 & 41.3 & 20.0 \\
\hline & & & & 0.9 & 1.14 & 80.5 & 54.1 \\
\hline \multirow[t]{2}{*}{7} & Vineyard Sound 1, & 59 & $13-39$ & 46.7 & 1.24 & -1.5 & 0.5 \\
\hline & surface & & & 49.2 & 1.09 & -1.5 & 1.3 \\
\hline \multirow[t]{3}{*}{8} & Vineyard Sound 2, & 50 & $10-39$ & 48.4 & 0.99 & -1.8 & -0.3 \\
\hline & surface & & & 47.2 & 1.09 & -1.8 & -0.7 \\
\hline & & & & 47.9 & 1.05 & -1.8 & -0.1 \\
\hline \multirow[t]{4}{*}{9} & Vineyard Sound 3, & 84 & nd & 52.0 & 1.05 & -2.2 & 2.7 \\
\hline & surface & & & 52.1 & 1.07 & 22.1 & 22.8 \\
\hline & & & & 51.9 & 1.07 & 44.4 & 45.4 \\
\hline & & & & 51.4 & 1.04 & 90.7 & 83.0 \\
\hline \multirow[t]{7}{*}{10} & Costa Rica Dome, & 79 & $26-58$ & 41.6 & 0.93 & -0.1 & 0.6 \\
\hline & Sta. $2(30 \mathrm{~m})$ & & & 35.0 & 0.92 & -0.0 & 0.1 \\
\hline & & & & 31.4 & 0.91 & 22.2 & 24.5 \\
\hline & & & & 26.6 & 0.94 & 21.5 & 20.2 \\
\hline & & & & 32.7 & 0.86 & 43.5 & 46.4 \\
\hline & & & & 36.1 & 0.87 & 88.8 & 88.3 \\
\hline & & & & 38.7 & 0.88 & 85.1 & 90.6 \\
\hline \multirow[t]{3}{*}{11} & Costa Rica Dome, & 93 & na & 46.5 & 0.14 & -0.3 & na \\
\hline & Sta. $3(2 \mathrm{~m})$ & & & 44.3 & 0.14 & 0.0 & na \\
\hline & & & & 44.7 & 0.11 & 22.3 & na \\
\hline
\end{tabular}


Table 1. Continued.

\begin{tabular}{|c|c|c|c|c|c|c|c|}
\hline Expt & $\begin{array}{l}\text { Organisms or } \\
\text { field location } \\
\text { and depth }\end{array}$ & $\begin{array}{l}\text { Duration of } \\
\text { incubation }(d)\end{array}$ & $\begin{array}{l}\text { Days of nitrite } \\
\text { accumulation }\end{array}$ & $\begin{array}{l}\text { Maximum accu- } \\
\text { mulated nitrite } \\
(\mu \mathrm{mol} \mathrm{L}-1)\end{array}$ & $\begin{array}{c}\Delta[\text { Nitrate }] \div \\
\Delta[\text { Ammonium }]\end{array}$ & $\begin{array}{c}\delta^{18} \mathrm{O}_{\mathrm{H}_{2} \mathrm{O}}(\% \text { vs. } \\
\text { VSMOW)* }\end{array}$ & $\begin{array}{c}\delta^{18} \mathrm{O}_{\mathrm{NO}_{3}, \text { nit }}(\% \text { } \\
\text { vs. VSMOW } \dagger\end{array}$ \\
\hline \multirow{5}{*}{12} & \multirow{5}{*}{$\begin{array}{l}\text { Costa Rica Dome, } \\
\text { Sta. } 3(20 \mathrm{~m})\end{array}$} & \multirow{5}{*}{113} & \multirow{5}{*}{ na } & 44.7 & 0.14 & 42.9 & na \\
\hline & & & & 46.4 & 0.20 & 87.6 & na \\
\hline & & & & 31.2 & 0.05 & 86.5 & na \\
\hline & & & & 46.3 & 0.13 & -0.1 & na \\
\hline & & & & 42.0 & 0.04 & 42.3 & na \\
\hline \multirow[t]{5}{*}{13} & Eastern Tropical & \multirow[t]{5}{*}{ nd } & \multirow[t]{5}{*}{ nd } & nd & 1.61 & 0.2 & 3.5 \\
\hline & South Pacific, & & & nd & 1.53 & 0.5 & 5.2 \\
\hline & Sta. 9 (111 m) & & & nd & 1.46 & 22.1 & 18.8 \\
\hline & & & & nd & 1.50 & 22.5 & 20.7 \\
\hline & & & & nd & 1.87 & 46.3 & 37.7 \\
\hline
\end{tabular}

nd, not determined because there was too little nitrite or sampled too infrequently; na, not applicable because nitrate was not produced

* Uncertainties in $\delta^{18} \mathrm{O}_{\mathrm{H}_{2} \mathrm{O}}$ were less than $0.5 \%$.

$\dagger$ Uncertainties in $\delta^{18} \mathrm{O}_{\mathrm{NO}_{3}}$ were less than $0.5 \%$.

Amersham Biosciences Ultrospec 2100 spectrophotometer using a Gilson 220XL autosampler. Nitrate plus nitrite was measured using hot vanadium reduction to nitric oxide (Cox 1980; Garside 1982) and detection on a Monitor Labs Nitrogen Oxides Detector (model No. 8840). Bracketing standards were used for each method, with concentrations ranging from 0 to $100 \mu \mathrm{mol} \mathrm{L}-1$. Measurement precision was $0.2 \mu \mathrm{mol} \mathrm{L}^{-1}$ for all methods.

Isotopic analysis-Nitrite $\delta^{15} \mathrm{~N}$ and $\delta^{18} \mathrm{O}$ measurements were made using the azide method (McIlvin and Altabet 2005). Samples were analyzed in duplicate against three standards with known isotopic values: N-23, N-7373, and N-10219 (Casciotti et al. 2007), which were analyzed in triplicate with each run and are reported in per mil (\%) notation vs. atmospheric $\mathrm{N}_{2}$ (air) for $\delta^{15} \mathrm{~N}$ and vs.
VSMOW for $\delta^{18} \mathrm{O}$ measurements. Sample volumes were injected to obtain 5-20 nmoles of $\mathrm{N}_{2} \mathrm{O}$ with matching standard amounts. The standard deviation for $\delta^{15} \mathrm{~N}_{\mathrm{NO}_{2}}$ and $\delta^{18} \mathrm{O}_{\mathrm{NO}_{2}}$ analyses was better than $0.2 \%$ and $0.3 \%$, respectively, within and between runs.

Water $\delta^{18} \mathrm{O}$ values were measured by equilibration of oxygen atoms with nitrite, followed by a modified azide method (McIlvin and Casciotti 2006). Samples were analyzed in duplicate and reported on the VSMOW reference scale by calibration against replicate $\delta^{18} \mathrm{O}_{\mathrm{H}_{2} \mathrm{O}}$ and $\delta^{18} \mathrm{O}_{\mathrm{NO}_{2}}$ reference materials analyzed in parallel (McIlvin and Casciotti 2006). The standard deviation for $\delta^{18} \mathrm{O}_{\mathrm{H}_{2} \mathrm{O}}$ analyses is $0.3 \%$, within and between runs.

Nitrate $\delta^{15} \mathrm{~N}$ and $\delta^{18} \mathrm{O}$ values were measured using the denitrifier method (Sigman et al. 2001; Casciotti et al. 2002; McIlvin and Casciotti 2011). Samples were analyzed in

\begin{tabular}{|c|c|c|c|c|c|}
\hline \multirow{2}{*}{$\begin{array}{c}\text { Experiment } \\
\text { No. }\end{array}$} & \multirow{2}{*}{ Type } & \multirow{2}{*}{$\begin{array}{l}\text { Organism or } \\
\text { location }\end{array}$} & \multicolumn{3}{|c|}{ Measured in experiment } \\
\hline & & & $\delta^{18} \mathrm{ONO}_{3}$, final & $x_{\mathrm{AO}}$ from $\mathrm{NO}_{3}^{-}$ & $x_{\mathrm{AO}}$ from $\mathrm{NO}_{2}^{-}$ \\
\hline$\overline{1}$ & \multirow{6}{*}{ 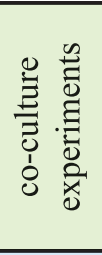 } & \multirow{4}{*}{$\mathrm{AOB}+\mathrm{NOB}$} & 1 & 1 & 1 \\
\hline 2 & & & 2 & 2 & 2 \\
\hline 3 & & & 3 & 3 & \\
\hline 4 & & & 4 & 4 & 4 \\
\hline 5 & & \multirow{2}{*}{$\mathrm{AOA}+\mathrm{NOB}$} & 5 & 5 & 5 \\
\hline 6 & & & 6 & 6 & \\
\hline 7 & \multirow{7}{*}{ 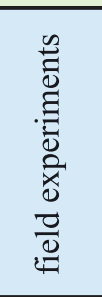 } & \multirow{3}{*}{$\begin{array}{l}\text { Vineyard } \\
\text { Sound }\end{array}$} & 7 & & \\
\hline 8 & & & 8 & & \\
\hline 9 & & & 9 & 9 & 9 \\
\hline 10 & & \multirow{3}{*}{$\begin{array}{l}\text { Costa Rica } \\
\text { Dome }\end{array}$} & 10 & 10 & 10 \\
\hline 11 & & & & & 11 \\
\hline 12 & & & & & 12 \\
\hline 13 & & ETSP & 13 & 13 & \\
\hline
\end{tabular}

Fig. 2. A schematic of the experiments indicating the parameters that were measured in each experiment. 
duplicate against three reference materials with known isotopic values: USGS32, USGS34, and USGS35 (Böhlke et al. 2003) and are reported vs. air for $\delta^{15} \mathrm{~N}$ and VSMOW for $\delta^{18} \mathrm{O}$. Each reference material was analyzed six times per set of 60 samples. The standard deviation for $\delta^{15} \mathrm{~N}_{\mathrm{NO}_{3}}$ and $\delta^{18} \mathrm{O}_{\mathrm{NO}_{3}}$ analyses was better than $0.2 \%$ and $0.3 \%$, respectively, within and between runs. Samples containing both nitrite and nitrate were treated with sulfamic acid to remove nitrite prior to nitrate isotopic analysis (Granger and Sigman 2009).

Calculating exchange and kinetic isotope effects$\delta^{18} \mathrm{O}_{\mathrm{NO}_{2}}$ and $\delta^{18} \mathrm{O}_{\mathrm{NO}_{3}}$ produced during nitrification $\left(\delta^{18} \mathrm{O}_{\mathrm{NO}_{2} \text {,nit }}\right.$ and $\delta^{18} \mathrm{O}_{\mathrm{NO}_{3}, \text { nit }}$, respectively) depend on many factors, including the $\delta^{18} \mathrm{O}$ values of substrates $\left(\delta^{18} \mathrm{O}_{\mathrm{O}_{2}}\right.$ and $\delta^{18} \mathrm{O}_{\mathrm{H}_{2} \mathrm{O}}$ ), isotopic fractionation associated with incorporation of these substrates during ammonia oxidation $\left({ }^{18} \varepsilon_{\mathrm{k}, \mathrm{O}_{2}}\right.$, $\left.{ }^{18} \varepsilon_{\mathrm{k}, \mathrm{H}_{2} \mathrm{O}, 1}\right)$ and nitrite oxidation $\left({ }^{18} \varepsilon_{\mathrm{k}, \mathrm{H}_{2} \mathrm{O}, 2}\right)$, and oxygen isotope exchange between nitrite and $\mathrm{H}_{2} \mathrm{O}\left({ }^{18} \varepsilon_{\text {eq }}\right.$; Fig. 1; Casciotti et al. 2010, 2011; Snider et al. 2010). The fraction of nitrite oxygen atoms exchanged with $\mathrm{H}_{2} \mathrm{O}$ during nitrite oxidation $\left(x_{\mathrm{NO}}\right)$ is generally negligible (Kumar et al. 1983; DiSpirito and Hooper 1986; Buchwald and Casciotti 2010), while the exchange during ammonia oxidation $\left(x_{\mathrm{AO}}\right)$ is highly variable and dependent on organism and growth conditions (Dua et al. 1979; Andersson et al. 1982; Casciotti et al. 2010). The oxygen isotope effect for nitrite oxidation $\left({ }^{18} \varepsilon_{\mathrm{k}, \mathrm{NO}_{2}}\right)$ will also affect $\delta^{18} \mathrm{O}_{\mathrm{NO}_{2}}$ and $\delta^{18} \mathrm{O}_{\mathrm{NO}_{3}}$ if nitrite oxidation is incomplete (Buchwald and Casciotti 2010) but is excluded here in the formulation for $\delta^{18} \mathrm{O}_{\mathrm{NO}_{3, \text { final }}}$.

Equation 1 describes the $\delta^{18} \mathrm{O}_{\mathrm{NO}_{2}}$ produced through ammonia oxidation (Casciotti et al. 2010), and Eq. 2 describes the $\delta^{18} \mathrm{O}_{\mathrm{NO}_{3}}$ produced when nitrite oxidation goes to completion $\left(\delta^{18} \mathrm{O}_{\mathrm{NO}_{3, \text { final }}}\right.$; Buchwald and Casciotti 2010). The symbols are as defined above.

$$
\begin{gathered}
\delta^{18} \mathrm{O}_{\mathrm{NO}_{2}}=\left[\frac{1}{2}\left(\delta^{18} \mathrm{O}_{\mathrm{O}_{2}}-{ }^{18} \varepsilon_{\mathrm{O}_{2}}\right)+\right. \\
\left.\frac{1}{2}\left(\delta^{18} \mathrm{O}_{\mathrm{H}_{2} \mathrm{O}}-{ }^{18} \varepsilon_{\mathrm{k}, \mathrm{H}_{2} \mathrm{O}, 1}\right)\right]\left(1-x_{\mathrm{AO}}\right) \\
+\left(\delta^{18} \mathrm{O}_{\mathrm{H}_{2} \mathrm{O}}+{ }^{18} \varepsilon_{\mathrm{eq}}\right)\left(x_{\mathrm{AO}}\right) \\
\delta^{18} \mathrm{O}_{\mathrm{NO}_{3}, \text { final }}=\frac{2}{3}\left[\left(1-x_{\mathrm{NO}}\right) \delta^{18} \mathrm{O}_{\mathrm{NO}_{2}}+x_{\mathrm{NO}}\right. \\
\left.\left(\delta^{18} \mathrm{O}_{\mathrm{H}_{2} \mathrm{O}}+{ }^{18} \varepsilon_{\mathrm{eq}}\right)\right]+\frac{1}{3}\left(\delta^{18} \mathrm{O}_{\mathrm{H}_{2} \mathrm{O}}-\right. \\
\left.{ }^{18} \varepsilon_{\mathrm{k}, \mathrm{H}_{2} \mathrm{O}, 2}\right)
\end{gathered}
$$

The first term in Eq. 1 represents the enzymatic incorporation of $\mathrm{O}_{2}$ and $\mathrm{H}_{2} \mathrm{O}$ during ammonia oxidation to nitrite. This incorporation signal can be partially modified if exchange $\left(x_{\mathrm{AO}}\right)$ occurs between nitrite and $\mathrm{H}_{2} \mathrm{O}$ during ammonia oxidation. The second term represents the $\delta^{18} \mathrm{O}$ contribution of $\mathrm{O}$ atoms that are added by this exchange. The first term in Eq. 2 represents the $\delta^{18} \mathrm{O}$ value of the substrate nitrite used by nitrite oxidizers, which may be modified by exchange of oxygen atoms between nitrite and $\mathrm{H}_{2} \mathrm{O}$ during nitrite oxidation $\left(x_{\mathrm{NO}}\right) . x_{\mathrm{NO}}$ is included here for completeness, although it has been found to have a negligible effect on $\delta^{18} \mathrm{O}_{\mathrm{NO}_{3}}$,nit (DiSpirito and Hooper 1986; Friedman et al. 1986; Buchwald and Casciotti 2010). The second term describes the $\delta^{18} \mathrm{O}$ value of $\mathrm{H}_{2} \mathrm{O}$ incorporated during nitrite oxidation to nitrate.

If Eq. 1 is arranged to group $\delta^{18} \mathrm{O}_{\mathrm{H}_{2} \mathrm{O}}$ terms (Eq. 3), the equation can be used to interpret the slope and intercept of the linear regression between $\delta^{18} \mathrm{O}_{\mathrm{NO}_{2}}$ and $\delta^{18} \mathrm{O}_{\mathrm{H}_{2} \mathrm{O}}$.

$$
\begin{aligned}
\delta^{18} \mathrm{O}_{\mathrm{NO}_{2}}= & {\left[\frac{1}{2}+\frac{1}{2} x_{\mathrm{AO}}\right] \delta^{18} \mathrm{O}_{\mathrm{H}_{2} \mathrm{O}} } \\
+ & \frac{1}{2}\left[\left(\delta^{18} \mathrm{O}_{\mathrm{O}_{2}}-{ }^{18} \varepsilon_{\mathrm{k}, \mathrm{O}_{2}}-{ }^{18} \varepsilon_{\mathrm{k}, \mathrm{H}_{2} \mathrm{O}, 1}\right)\right. \\
& \left.\left(1-x_{\mathrm{AO}}\right)\right]+{ }^{18} \varepsilon_{\mathrm{eq}} x_{\mathrm{AO}}
\end{aligned}
$$

The first term represents the slope of the linear regression and is dependent on the fraction of $\mathrm{O}$ incorporated enzymatically from $\mathrm{H}_{2} \mathrm{O}(1 / 2)$ and $x_{\text {AO }}$. If there is no exchange $\left(x_{\mathrm{AO}}=0\right)$ a slope of 0.5 would be expected, and if there is full exchange $\left(x_{\mathrm{AO}}=1\right)$ the slope would be 1 (Fig. 3a). The last two terms of Eq. 3 represent the intercept, which refers to the $\delta^{18} \mathrm{O}$ value of nitrite produced at a $\delta^{18} \mathrm{O}_{\mathrm{H}_{2} \mathrm{O}}$ value of $0 \%$. The intercept can be used to calculate the sum of the incorporation isotope effects for ammonia oxidation $\left({ }^{18} \varepsilon_{\mathrm{k}, \mathrm{O}_{2}}+{ }^{18} \varepsilon_{\mathrm{k}, \mathrm{H}_{2} \mathrm{O}, 1}\right)$ by using the exchange $\left(x_{\mathrm{AO}}\right)$ calculated from the slope and assuming $\delta^{18} \mathrm{O}_{\mathrm{O}_{2}}=+24.2 \%$ (appropriate for seawater equilibrated with tropospheric $\mathrm{O}_{2}$, Kroopnick and Craig 1972 ) and ${ }^{18} \varepsilon_{\mathrm{eq}}=+12.5 \%$ o $\pm 0.5 \%$ (applicable for experiments at room temperature; C. Buchwald and K. L. Casciotti unpubl.).

$$
\begin{aligned}
\delta^{18} \mathrm{O}_{\mathrm{NO}_{3}, \text { final }}=\left[\frac{2}{3}+\frac{1}{3} x_{\mathrm{AO}}\right] \delta^{18} \mathrm{O}_{\mathrm{H}_{2} \mathrm{O}} \\
+\frac{1}{3}\left[\left(\delta^{18} \mathrm{O}_{\mathrm{O}_{2}}-{ }^{18} \varepsilon_{\mathrm{k}, \mathrm{O}_{2}}-{ }^{18} \varepsilon_{\mathrm{k}, \mathrm{H}_{2} \mathrm{O}, 1}\right)\right. \\
\\
\left.\left(1-x_{\mathrm{AO}}\right)-{ }^{18} \varepsilon_{\mathrm{k}, \mathrm{H}_{2} \mathrm{O}, 2}\right] \\
+\frac{2}{3}{ }^{18} \varepsilon_{\mathrm{eq}} x_{\mathrm{AO}}
\end{aligned}
$$

Equation 4 describes the full isotope systematics of nitrification, combining Eqs. 2 and 3. After substituting Eq. 3 into Eq. 2, we simplify by assuming that there is no exchange during nitrite oxidation $\left(x_{\mathrm{NO}}=0\right)$ (discussed above) and then regroup terms containing $\delta^{18} \mathrm{O}_{\mathrm{H}_{2} \mathrm{O}}$. The resulting Eq. 4 can be used to interpret the $\delta^{18} \mathrm{O}_{\mathrm{NO}_{3}}$ vs. $\delta^{18} \mathrm{O}_{\mathrm{H}_{2} \mathrm{O}}$ regression for experiments where ammonia is oxidized fully to nitrate (Fig. 3b). A slope of two thirds would indicate no exchange during ammonia oxidation $\left(x_{\mathrm{AO}}=0\right)$, while a slope of 1 would indicate full exchange $\left(x_{\mathrm{AO}}\right.$ $=1)$. The intercept of the nitrate regression is dependent on $\delta^{18} \mathrm{O}_{\mathrm{O}_{2}},{ }^{18} \varepsilon_{\mathrm{k}, \mathrm{O}_{2}},{ }^{18} \varepsilon_{\mathrm{k}, \mathrm{H}_{2} \mathrm{O}, 1},{ }^{18} \varepsilon_{\mathrm{k}, \mathrm{H}_{2} \mathrm{O}, 2},{ }^{18} \varepsilon_{\mathrm{eq}}$, and $x_{\mathrm{AO}}$. Using values from the intercept of the nitrite regression for ${ }^{18} \varepsilon_{\mathrm{k}, \mathrm{O}_{2}}+$ ${ }^{18} \varepsilon_{\mathrm{k}, \mathrm{H}_{2} \mathrm{O}, 1}$ and the exchange $\left(x_{\mathrm{AO}}\right)$ calculated from the slope in Eq. 4, one can determine ${ }^{18} \varepsilon_{\mathrm{k}, \mathrm{H}_{2} \mathrm{O}, 2}$ assuming $\delta^{18} \mathrm{O}_{\mathrm{O}_{2}}=+24.2 \%$ and ${ }^{18} \varepsilon_{\text {eq }}=+12.5 \%$, as described above. Uncertainty in ${ }^{18} \varepsilon_{\text {eq }}( \pm$ $0.5 \%$ ) is propagated through to incorporation isotope effects. 

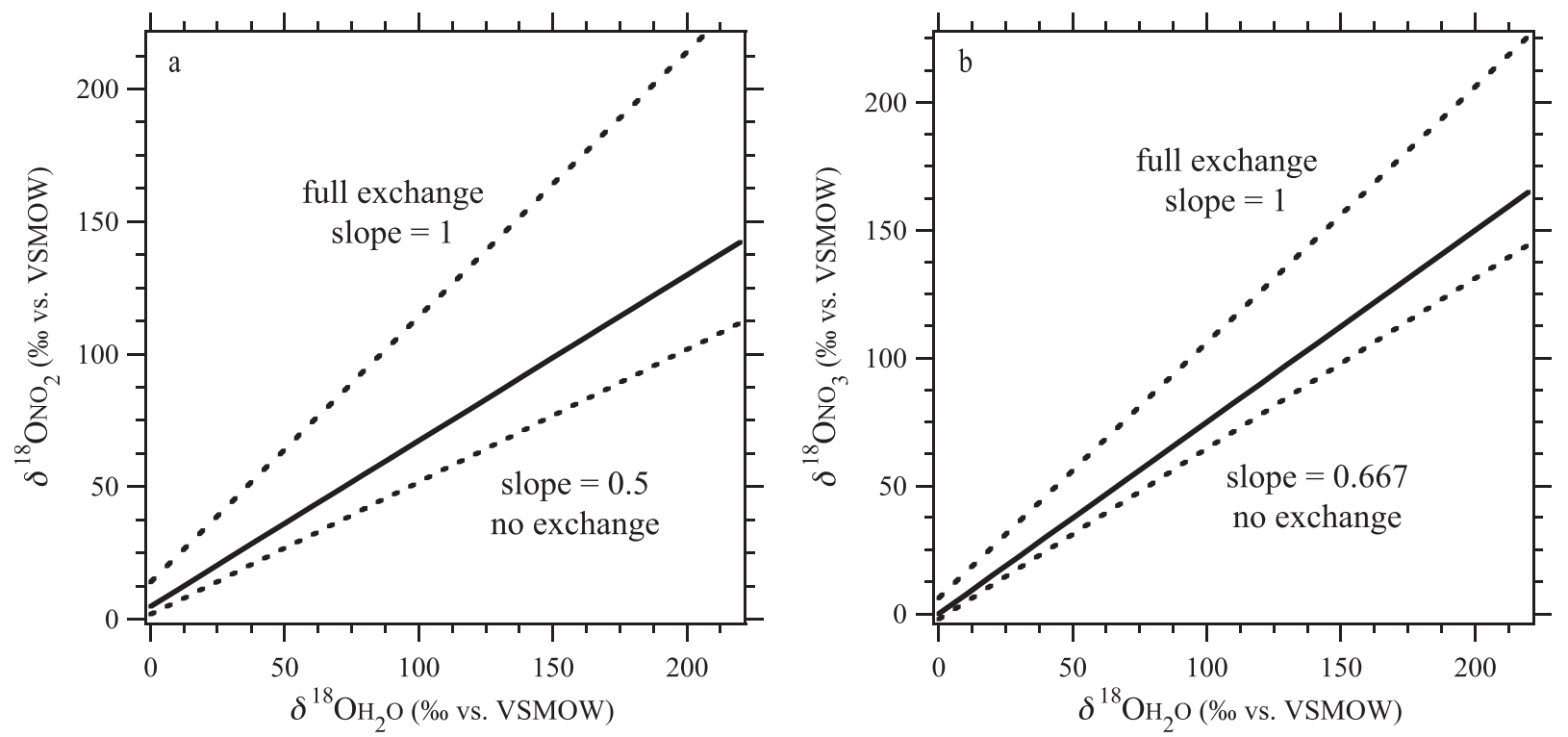

Fig. 3. A conceptual model of expected results from coculture experiments with varying $\delta^{18} \mathrm{O}_{\mathrm{H}_{2} \mathrm{O}}$ media. (a) $\delta^{18} \mathrm{O}_{\mathrm{H}_{2} \mathrm{O}} \mathrm{vs} \delta^{18} \mathrm{O}_{\mathrm{NO}_{2}}$ (b) $\delta^{18} \mathrm{O}_{\mathrm{H}_{2} \mathrm{O}}$ vs. $\delta^{18} \mathrm{O}_{\mathrm{NO}_{3} \text {.inal }}$. In both plots the $0 \%$ and $100 \%$ exchange scenarios are indicated in dotted lines, and an exchange of $25 \%$ is shown with the solid line. The water incorporation isotope effects used in the model are ${ }^{18} \varepsilon_{\mathrm{k}_{\mathrm{k}, \mathrm{O}_{2}}}+{ }^{18} \varepsilon_{\mathrm{k}, \mathrm{H}_{2} \mathrm{O}, 1}=20 \%$ and ${ }^{18} \varepsilon_{\mathrm{k}, \mathrm{H}_{2} \mathrm{O}, 2}=10 \%$.

Kinetic isotope fractionation of nitrite during oxidation $\left({ }^{18} \varepsilon_{\mathrm{k}, \mathrm{NO}_{2}}\right.$; Fig. 1) may complicate interpretation of the intercept of accumulated nitrite and of nitrate isotopes in intermediate samples, when oxidation is incomplete. Inverse fractionation of oxygen atoms in nitrite during nitrite oxidation (Buchwald and Casciotti 2010) will cause nitrite $\delta^{18} \mathrm{O}_{\mathrm{NO}_{2}}$ values to be lower and $\delta^{18} \mathrm{O}_{\mathrm{NO}_{3}}$ values to be higher than if no nitrite oxidation had occurred, or if nitrite oxidation were complete. Therefore, in order to interpret intermediate samples, it is important to know whether and how much nitrite oxidation has occurred at the time that the sample is collected. In order to simplify the interpretation, we sampled for $\delta^{18} \mathrm{O}_{\mathrm{NO}_{2}}$ early in an experiment (prior to commencement of nitrite oxidation), for interpretation of the incorporation isotope effects associated with ammonia oxidation, and for $\delta^{18} \mathrm{O}_{\mathrm{NO}_{3}}$ values late in the experiment (after all the ammonium had been converted to nitrate $\delta^{18} \mathrm{O}_{\mathrm{NO}_{3, \text { final }}}$ ), for interpretation of the incorporation isotope effect during nitrite oxidation. We should note here that the inverse kinetic isotope effect only affects the intercept at intermediate time points and does not affect the slope of $\delta^{18} \mathrm{O}_{\mathrm{NO}_{2}}$ or $\delta^{18} \mathrm{O}_{\mathrm{NO}_{3} \text {,final }}$ vs. $\delta^{18} \mathrm{O}_{\mathrm{H}_{2} \mathrm{O}}$ regressions, so long as all bottles are sampled at the same time (the same progress of ammonia and nitrite oxidation).

\section{Results}

Nitrite accumulation in coculture incubations-Total incubation times for the laboratory coculture experiments (CCEs 1-6) ranged from 3 to $59 \mathrm{~d}$, with little accumulation of nitrite (Table 1; Fig. 4a-c). In the first three experiments (CCEs 1, 2, 3), with C-113a and N. mobilis, the ammonium was completely converted to nitrate within $6 \mathrm{~d}$. Only a small amount (less than $2 \mu \mathrm{mol} \mathrm{L}^{-1}$ ) of nitrite accumulated in these experiments, for a maximum of $4 \mathrm{~d}$. In $\operatorname{CCE} 4$, where we manipulated the AOB: NOB abundance ratio, ammonium was oxidized fully to nitrate in 3,7 , or $16 \mathrm{~d}$, depending on the $N$. mobilis cell density. In this experiment, ammonia and nitrite oxidation became decoupled at lower densities of nitrite-oxidizing bacteria, and increasing amounts of nitrite accumulated $\left(1,25\right.$, and $\left.45 \mu \mathrm{mol} \mathrm{L}^{-1}\right)$ at lower AOB : NOB ratios (Table 1; Fig. 4b). In CCEs 5 and 6, with AOA and $N$. mobilis, it took 18-59 d for the ammonium to be consumed because of the slower growth rate of the ammonia-oxidizing archaea (Santoro and Casciotti 2011). These incubations had an initial nitrite concentration of $7 \mu \mathrm{mol} \mathrm{L}-1$ as a result of carry-over from the AOA inoculum, which was oxidized to nitrate before the first time point (Fig. 4c). Afterward, NOB maintained low levels (less than $1 \mu \mathrm{mol} \mathrm{L}-1$ ) of nitrite in the medium, indicating that ammonia and nitrite oxidation were tightly coupled (Fig. 4c). At the end of the experiment, final $\delta^{18} \mathrm{O}_{\mathrm{NO}_{3}}$ values were corrected for nitrate produced through the oxidation of the initial nitrite in order to focus on nitrate produced from ammonium in the variable ${ }^{18} \mathrm{O}$-enriched media. This was done by calculating the $\delta^{18} \mathrm{O}_{\mathrm{NO}_{3}}$ that would have been produced from the preexisting nitrite (with a known $\delta^{18} \mathrm{O}_{\mathrm{NO}_{2}}$ value) using Eq. 2. Then the $\delta^{18} \mathrm{O}_{\mathrm{NO}_{3}}$ produced was subtracted by mass balance from the $\delta^{18} \mathrm{O}_{\mathrm{NO}_{3, \text { final }}}$ for each bottle.

Nitrite accumulation in field incubations-It took longer for field populations to fully oxidize the added ammonium, with incubations lasting for 50 to $179 \mathrm{~d}$ before complete oxidation was observed (Table 1; Fig. 4d-f). In FEs 7 and 8 from Vineyard Sound, nitrite accumulated to $50 \mu \mathrm{mol} \mathrm{L}-1$ before being fully oxidized to nitrate after $50-59 \mathrm{~d}$ (Fig. 4d). The accumulated nitrite was present for at least $13 \mathrm{~d}$ and may have persisted for as long as $40 \mathrm{~d}$, although the sampling frequency was not high enough to determine the exact duration. For the third Vineyard Sound experiment (FE 9) 

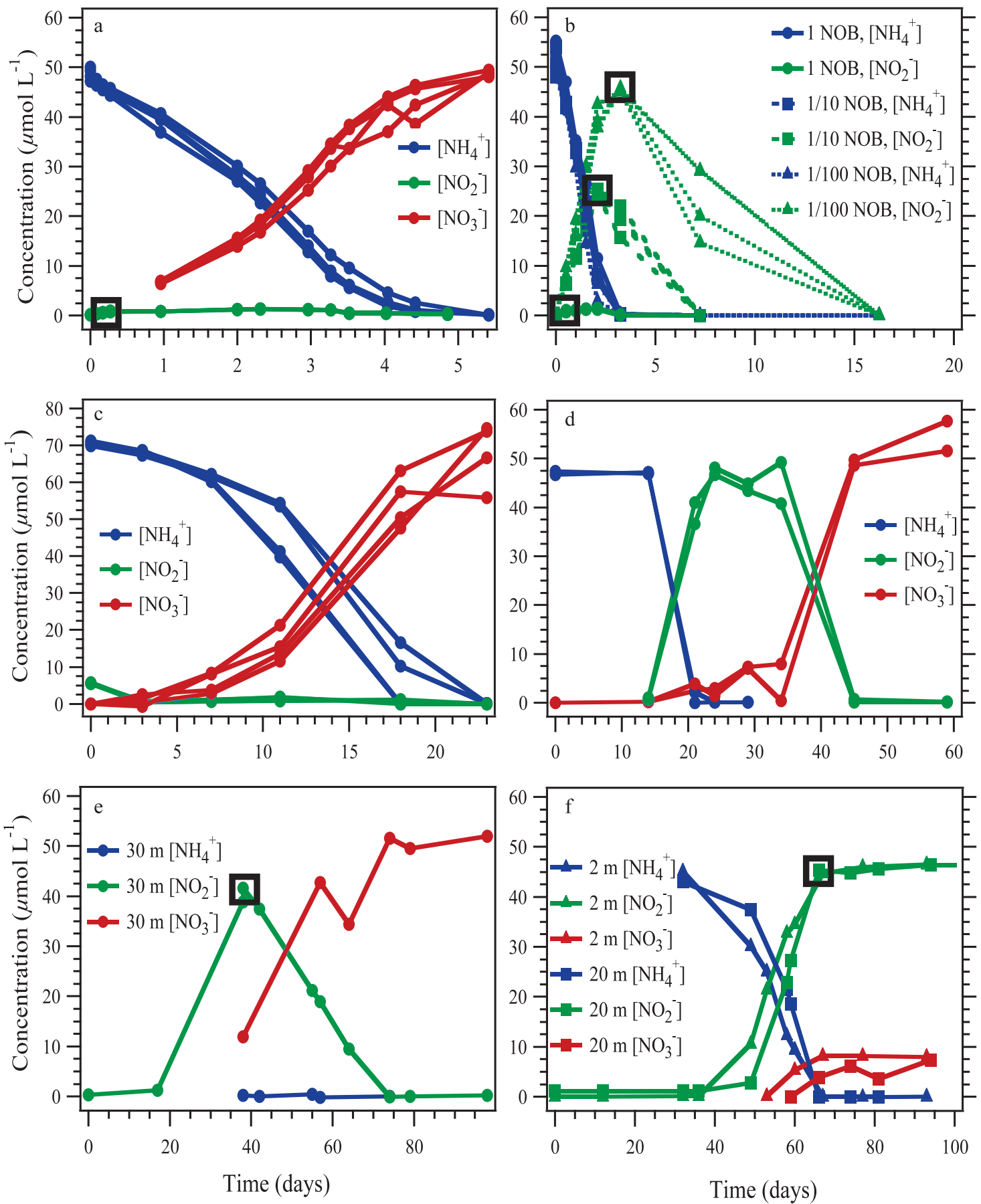

Fig. 4. Time course of ammonium, nitrite, and nitrate concentrations for coculture and field experiments: (a) CCE 2, C-113a, and $N$. mobilis, (b) CCE 4, C-113a, and varied N. mobilis, (c) CCE 5, AOA CN25, and N. mobilis, (d) FE 7, Vineyard Sound 1, (e) FE 10, CRD, Sta. 2, and (f) FEs 11 and 12, CRD, Sta. 3. Black squares represent which nitrite samples were used for calculations in Tables 2 and 3 and Fig. 5a. Nitrate concentration data for CCE 4 (removed for clarity) confirm $\mathrm{N}$ mass balance in the experiment.

oxidation of ammonium to nitrate was completed within $84 \mathrm{~d}$ (Table 1), and nitrite accumulated to a maximum concentration of $\sim 52 \mu \mathrm{mol} \mathrm{L}-1$ for as long as $53 \mathrm{~d}$. In each of the Vineyard Sound experiments, the indicated durations may overestimate the true duration because sampling frequency was low near the end of the experiments.

In the Costa Rica Dome, incubations were successful (nitrification was detected) at two stations (2 and 3). At Sta.
2 , nitrification occurred in water collected from the primary nitrite maximum (FE 10), while the incubations at Sta. 3 were successful from both the surface (FE 11) and the primary nitrite maximum (FE 12). In FE 10, complete oxidation of ammonium to nitrate occurred in seven of the eight bottles, including at least one from each of the four $\delta^{18} \mathrm{O}_{\mathrm{H}_{2} \mathrm{O}}$ values, and was completed in $79 \mathrm{~d}$ (Table 1). There was a variable lag in initiation of nitrification among the 

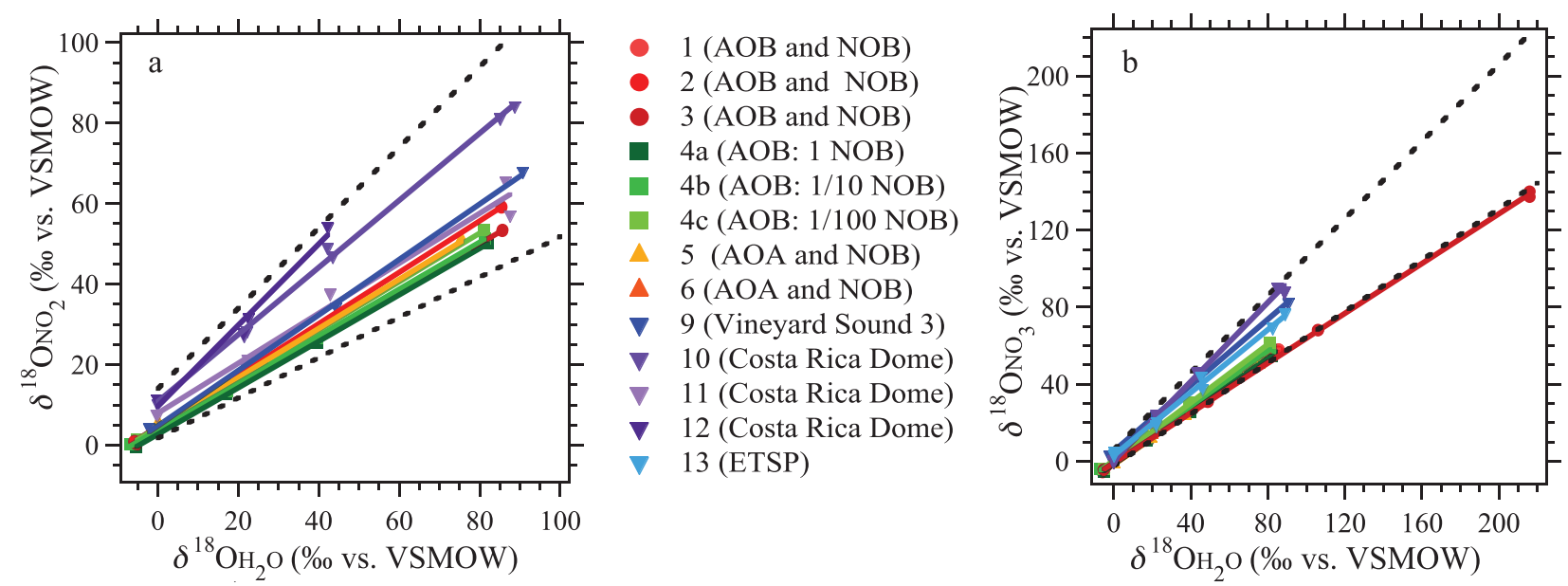

Fig. 5. (a) $\delta^{18} \mathrm{O}_{\mathrm{H}_{2} \mathrm{O}}$ vs. intermediate $\delta^{18} \mathrm{O}_{\mathrm{NO}_{2}}$ in eight experiments and (b) $\delta^{18} \mathrm{O}_{\mathrm{H}_{2} \mathrm{O}}$ vs. final produced $\delta^{18} \mathrm{O}_{\mathrm{NO}_{3}}$ for nine different experiments. In both plots the $0 \%$ and $100 \%$ exchange scenarios are indicated in dotted lines.

incubation bottles, and therefore the samples collected represent differing stages of nitrification. We also measured different amounts of accumulating nitrite (26 to $41 \mu \mathrm{mol} \mathrm{L}-1)$ and durations of nitrite accumulation $(26$ $58 \mathrm{~d})$, depending on when each subsample was collected. Figure $4 \mathrm{e}$ shows the time course for one of seven bottles that had complete nitrification. In the other two experiments (FEs 11 and 12; Table 1) ammonia oxidation to nitrite was detected in five or six bottles out of eight, respectively, including at least one from each of the four $\delta^{18} \mathrm{O}_{\mathrm{H}_{2} \mathrm{O}}$ values. However, after ammonium was oxidized completely to nitrite no nitrate was produced in the subsequent 3 months (Fig. 4f), so only information on ammonia oxidation can be taken from these two experiments.

In the ETSP the smaller amounts of ammonium ( $1 \mu \mathrm{mol} \mathrm{L})^{-1}$ or $5 \mu \mathrm{mol} \mathrm{L}^{-1}$ ) added to incubations from below the primary nitrite maximum were completely oxidized to nitrate within 31-179 d (Table 1). Bottles were sampled infrequently for nitrite determination, so we do not know the exact amount and duration of accumulation; however, the maximum amount of nitrite accumulation would be $1 \mu \mathrm{mol} \mathrm{L}-1$ or $5 \mu \mathrm{mol} \mathrm{L}-1$, respectively, based on the ammonium additions. After $17 \mathrm{~d}$ of incubation there was a small amount of nitrite $\sim 0.2 \mu \mathrm{mol} \mathrm{L}^{-1}$ in some bottles from both $1 \mu \mathrm{mol} \mathrm{L}-1$ and $5 \mu \mathrm{mol} \mathrm{L}-1$ ammonium experiments below the primary nitrite maximum, indicating that it was likely that nitrification was occurring. These bottles had no nitrite left after $31 \mathrm{~d}$. In the two surface incubations ammonium had not been completely oxidized to nitrate after $179 \mathrm{~d}$, and they will not be discussed further.

Oxygen isotopic exchange during ammonia oxidationType II regressions were conducted in Matlab (Mathworks) to calculate the slopes and intercepts of $\delta^{18} \mathrm{O}_{\mathrm{NO}_{2}}$ vs. $\delta^{18} \mathrm{O}_{\mathrm{H}_{2} \mathrm{O}}$ data (Fig. 5a) and $\delta^{18} \mathrm{O}_{\mathrm{NO}_{3} \text {,final }}$ vs. $\delta^{18} \mathrm{O}_{\mathrm{H}_{2} \mathrm{O}}$ data (Fig. 5b) from 8 of 13 and 9 of 13 experiments, respectively (Fig. 2), to account for measurement error in both $\mathrm{x}$ $\left(\delta^{18} \mathrm{O}_{\mathrm{H}_{2} \mathrm{O}}\right)$ and y $\left(\delta^{18} \mathrm{O}_{\mathrm{NO}_{2}}\right.$ or $\left.\delta^{18} \mathrm{O}_{\mathrm{NO}_{3, \text { final }}}\right)$. The calculations were conducted using a least squares cubic fit (York 1966; York et al. 2004).
The fraction of $\mathrm{O}$ atoms in nitrite exchanged with $\mathrm{H}_{2} \mathrm{O}$ during ammonia oxidation fraction $\left(x_{\mathrm{AO}}\right)$ was calculated from the slope of $\delta^{18} \mathrm{O}_{\mathrm{NO}_{2}}$ vs. $\delta^{18} \mathrm{O}_{\mathrm{H}_{2} \mathrm{O}}$ (Eq. 3; Table 2). An alternative estimate of $x_{\mathrm{AO}}$ was obtained from the slope of $\delta^{18} \mathrm{O}_{\mathrm{NO}_{3, \text { final }}}$ vs. $\delta^{18} \mathrm{O}_{\mathrm{H}_{2} \mathrm{O}}$ assuming $x_{\mathrm{NO}}=0$ (Eq. 4; Tables 2 and 3). The isotope effect for $\mathrm{O}$ atom incorporation during nitrite oxidation $\left({ }^{18} \varepsilon_{\mathrm{k}, \mathrm{H}_{2} \mathrm{O}, 2}\right)$ was calculated from the intercept of $\delta^{18} \mathrm{O}_{\mathrm{NO}_{3} \text {,final }}$ vs. $\delta^{18} \mathrm{O}_{\mathrm{H}_{2} \mathrm{O}}$ and the intermediate $\delta^{18} \mathrm{O}_{\mathrm{NO}_{2}}$ data (Eq. 4; Table 3), assuming $x_{\mathrm{NO}}=0$. Comparisons between the data, for example isotope effects from coculture vs. field experiments, were analyzed by using a $t$-test for two samples with equal variance. In these tests, $p$ values greater than 0.05 indicate there is no significant difference between the mean of the two populations. In the cases for which we compared calculated exchange from $\delta^{18} \mathrm{O}_{\mathrm{NO}_{2}}$ and $\delta^{18} \mathrm{O}_{\mathrm{NO}_{3}}$ data in the same experiment, a paired $t$-test was conducted to determine whether there is a significant difference between each method for calculating exchange.

In CCEs 1, 2, 4a, and 5, where nitrite was maintained at low levels, the amount of exchange measured was relatively low. Estimates of $x_{\mathrm{AO}}$ from $\delta^{18} \mathrm{O}_{\mathrm{NO}_{2}}$ data ranged from 0.15 to 0.28 (Table 2 ), which closely matched previous estimates for C-113a grown under similar conditions (Casciotti et al. 2010). Estimates of $x_{\mathrm{AO}}$ from $\delta^{18} \mathrm{O}_{\mathrm{NO}_{3}}$ data were lower $(p=$ 0.03 ), ranging from -0.05 to 0.09 . It is generally expected that $x_{\mathrm{AO}}$ values from $\delta^{18} \mathrm{O}_{\mathrm{NO}_{3}}$ would be lower than those estimated from $\delta^{18} \mathrm{O}_{\mathrm{NO}_{2}}$ data because nitrate is an accumulated product recording the isotopic composition of nitrite that has seen increasing amounts of exchange over time, whereas $\delta^{18} \mathrm{O}_{\mathrm{NO}_{2}}$ is an instantaneous measurement of the total amount of exchange that has occurred at that time. The longer nitrite is accumulating before the $\delta^{18} \mathrm{O}_{\mathrm{NO}_{2}}$ is measured, the greater the expected difference between $x_{\mathrm{AO}}$ estimates. In the coculture experiments, $\delta^{18} \mathrm{O}_{\mathrm{NO}_{2}}$ was measured quite early in the experiment, and it was maintained at low levels for a short duration (3-5 d; Fig. 4a,c), which minimized abiotic exchange. Despite this, $x_{\mathrm{AO}}$ values from $\delta^{18} \mathrm{O}_{\mathrm{NO}_{3}}$ were still lower than from $\delta^{18} \mathrm{O}_{\mathrm{NO}_{2}}$ data, suggesting a contribution from abiotic exchange. 
Table 2. The fraction of $\mathrm{O}$ atoms in nitrite exchanged during ammonia oxidation $\left(x_{\mathrm{AO}}\right)$

\begin{tabular}{|c|c|c|c|c|}
\hline Experiment & $\begin{array}{c}\delta^{18} \mathrm{O}_{\mathrm{NO}_{3}} \text { vs. } \\
\delta^{18} \mathrm{O}_{\mathrm{H}_{2} \mathrm{O}} \text { slope }\end{array}$ & $\begin{array}{c}\delta^{18} \mathrm{O}_{\mathrm{NO}_{2}} \text { vs. } \\
\delta^{18} \mathrm{O}_{\mathrm{H}_{2} \mathrm{O}} \text { slope }\end{array}$ & $\begin{array}{l}x_{\mathrm{AO}} \text { calculated } \\
\text { from } \delta^{18} \mathrm{O}_{\mathrm{NO}_{3}}\end{array}$ & $\begin{array}{l}x_{\mathrm{AO}} \text { calculated } \\
\text { from } \delta^{18} \mathrm{O}_{\mathrm{NO}_{2}}\end{array}$ \\
\hline 1 & $0.70 \pm 0.00$ & $0.58 \pm 0.00$ & $0.09 \pm 0.05$ & $0.16 \pm 0.05$ \\
\hline 2 & $0.68 \pm 0.00$ & $0.64 \pm 0.00$ & $0.05 \pm 0.05$ & $0.28 \pm 0.05$ \\
\hline 3 & $0.65 \pm 0.00$ & nd & $-0.05 \pm 0.05$ & nd \\
\hline $4 a$ & $0.68 \pm 0.02$ & $0.58 \pm 0.00$ & $0.04 \pm 0.05$ & $0.15 \pm 0.05$ \\
\hline $4 b$ & $0.72 \pm 0.00$ & $0.60 \pm 0.00$ & $0.17 \pm 0.05$ & $0.19 \pm 0.05$ \\
\hline $4 c$ & $0.75 \pm 0.01$ & $0.61 \pm 0.00$ & $0.26 \pm 0.05$ & $0.21 \pm 0.05$ \\
\hline 5 & $0.69 \pm 0.00$ & $0.58 \pm 0.02$ & $0.07 \pm 0.05$ & $0.16 \pm 0.05$ \\
\hline 6 & $0.66 \pm 0.00$ & nd & $-0.01 \pm 0.05$ & nd \\
\hline 9 & $0.86 \pm 0.02$ & $0.68 \pm 0.01$ & $0.59 \pm 0.07$ & $0.35 \pm 0.05$ \\
\hline 10 & $1.05 \pm 0.05$ & $0.86 \pm 0.02$ & $1.15 \pm 0.15$ & $0.71 \pm 0.05$ \\
\hline 11 & na & $0.61 \pm 0.03$ & na & $0.22 \pm 0.05$ \\
\hline 12 & na & $1.03 \pm 0.09$ & na & $1.05 \pm 0.18$ \\
\hline 13 & $0.83 \pm 0.03$ & nd & $0.48 \pm 0.09$ & nd \\
\hline
\end{tabular}

nd, not determined because there was too little nitrite; na, not applicable because nitrate was not produced.

Decreasing the NOB:AOB ratio in CCE 4 led to increased nitrite accumulation and exchange, as seen in both $\delta^{18} \mathrm{O}_{\mathrm{NO}_{2}}$ and $\delta^{18} \mathrm{O}_{\mathrm{NO}_{3}}$ data (Tables 1 and 2). This trend continued in the field experiments where nitrite accumulated and persisted for even longer periods of time (30-60 d). In FEs 9-13 the exchange was generally high, varying between 0.22 and 1.0 , as determined from both $\delta^{18} \mathrm{O}_{\mathrm{NO}_{2}}$ and $\delta^{18} \mathrm{O}_{\mathrm{NO}_{3}}$ data (Table 2). In FEs 9 and $10, x_{\mathrm{AO}}$ values calculated from $\delta^{18} \mathrm{O}_{\mathrm{NO}_{3}}$ data were higher than estimated from $\delta^{18} \mathrm{O}_{\mathrm{NO}_{2}}$ data (FE 9, 0.59 vs. 0.36; and FE $10,1.15$ vs. 0.71 , respectively). This illustrates an exception to the conceptual argument given above, which occurs when nitrite undergoes further abiotic exchange between the time when $\delta^{18} \mathrm{O}_{\mathrm{NO}_{2}}$ is sampled and when $\delta^{18} \mathrm{O}_{\mathrm{NO}_{3}}$ is sampled, leading to a greater representation of exchange in the $\delta^{18} \mathrm{O}_{\mathrm{NO}_{3}}$ values. In keeping with this, consecutive measurements of $\delta^{18} \mathrm{O}_{\mathrm{NO}_{2}}$ from field experiments showed increasing amounts of exchange after the initial $\delta^{18} \mathrm{O}_{\mathrm{NO}_{2}}$ measurements were made, in contrast with coculture experiments (CCEs 1, 2, 4a, 5, 6), which showed little change in $\delta^{18} \mathrm{O}_{\mathrm{NO}_{2}}$ over time (not shown). In field experiments, we were not able to collect $\delta^{18} \mathrm{O}_{\mathrm{NO}_{2}}$ measurements early enough in the experiment to avoid inclusion of abiotic exchange, and we were not able to correct for it, so abiotic exchange is included in both $\delta^{18} \mathrm{O}_{\mathrm{NO}_{2}}$ data and $\delta^{18} \mathrm{O}_{\mathrm{NO}_{3}}$ data, although to a greater extent in the latter.

Oxygen incorporation isotope effects during nitrificationThe $y$-intercepts of the $\delta^{18} \mathrm{O}_{\mathrm{NO}_{2}}$ (or $\delta^{18} \mathrm{O}_{\mathrm{NO}_{3}}$ ) vs. $\delta^{18} \mathrm{O}_{\mathrm{H}_{2} \mathrm{O}}$ regressions (Eqs. 3, 4; Fig. 5; Table 3) represent the $\delta^{18} \mathrm{O}$ values of nitrite (or nitrate) produced in water with a $\delta^{18} \mathrm{O}_{\mathrm{H}_{2} \mathrm{O}}$ value of $0 \%$. The intercept will be dependent on the isotopic composition of oxygen atom sources $\left(\mathrm{H}_{2} \mathrm{O}\right.$ and $\mathrm{O}_{2}$ ), the isotope effects for $\mathrm{O}$ atom incorporation during nitrification, and the amount of $\mathrm{O}$ atom exchange between nitrite and $\mathrm{H}_{2} \mathrm{O}$. Therefore, if one determines the amount of exchange (from the slope) and measures or assumes $\delta^{18} \mathrm{O}$ values for $\mathrm{H}_{2} \mathrm{O}$ and dissolved oxygen, the isotope effects for $\mathrm{O}$ atom incorporation can be determined from $\delta^{18} \mathrm{O}_{\mathrm{NO}_{2}}$ and $\delta^{18} \mathrm{O}_{\mathrm{NO}_{3}}$ data (Eqs. 3, 4; Fig. 5; Tables 2 and 3).

The intercepts for $\delta^{18} \mathrm{O}_{\mathrm{NO}_{2}}$ in all experiments ranged from $+2.8 \%$ to $+9.5 \%$, increasing with increasing amounts

Table 3. The isotope effects for incorporation of oxygen and water during nitrification.

\begin{tabular}{|c|c|c|c|c|}
\hline Experiment & $\begin{array}{c}\delta^{18} \mathrm{O}_{\mathrm{NO}_{3} \text {, final }} \text { vs. } \delta^{18} \mathrm{O}_{\mathrm{H}_{2} \mathrm{O}} \\
\text { intercept }(\% 0)\end{array}$ & $\begin{array}{c}\delta^{18} \mathrm{O}_{\mathrm{NO}_{2}} \text { vs. } \delta^{18} \mathrm{O}_{\mathrm{H}_{2} \mathrm{O}} \\
\text { intercept }(\% 0)\end{array}$ & $\begin{array}{c}\text { Calculated } \\
{ }^{18} \varepsilon_{\mathrm{k}, \mathrm{O}_{2}}+{ }^{18} \varepsilon_{\mathrm{k}, \mathrm{H}_{2} \mathrm{O}, 1}(\% \mathrm{o})\end{array}$ & $\begin{array}{c}\text { Calculated } \\
{ }^{18} \varepsilon_{\mathrm{k}, \mathrm{H}_{2} \mathrm{O}, 2}(\% \mathrm{\% o})\end{array}$ \\
\hline 1 & $-1.5 \pm 0.0$ & $+3.5 \pm 0.1$ & $20.8 \pm 0.1$ & $9.7 \pm 0.2$ \\
\hline 2 & $-1.6 \pm 0.1$ & $+4.6 \pm 0.1$ & $21.0 \pm 0.2$ & $8.6 \pm 0.4$ \\
\hline 3 & $-0.9 \pm 0.2$ & nd & nd & nd \\
\hline $4 \mathrm{a}$ & $-1.0 \pm 0.5$ & $+2.8 \pm 0.2$ & $22.1 \pm 0.3$ & $5.8 \pm 1.9$ \\
\hline $4 b$ & $-0.4 \pm 0.1$ & $+3.0 \pm 0.1$ & $22.7 \pm 0.2$ & $6.6 \pm 0.5$ \\
\hline $4 \mathrm{c}$ & $+0.3 \pm 0.3$ & $+4.2 \pm 0.2$ & $20.3 \pm 0.3$ & $8.5 \pm 1.0$ \\
\hline 5 & $-1.7 \pm 0.1$ & $+5.3 \pm 0.4$ & $16.4 \pm 0.6$ & $12.4 \pm 0.6$ \\
\hline 6 & $+0.7 \pm 0.1$ & nd & nd & nd \\
\hline 9 & $+5.2 \pm 1.4$ & $+5.9 \pm 0.2$ & $19.7 \pm 0.6$ & $0.8 \pm 4.5$ \\
\hline 10 & $-0.7 \pm 1.6$ & $+9.5 \pm 0.6$ & $20.3 \pm 2.9$ & $27.2 \pm 5.7$ \\
\hline 11 & na & $+7.8 \pm 0.7$ & $11.4 \pm 1.1$ & na \\
\hline 12 & na & $+9.5 \pm 2.5$ & na & na \\
\hline 13 & $+1.3 \pm 1.4$ & nd & nd & nd \\
\hline
\end{tabular}

nd, not determined because there was too little nitrite; na, not applicable because nitrate was not produced or because there was full exchange. 
Table 4. $\quad \delta^{18} \mathrm{O}_{\mathrm{NO}_{3}}$ produced in field experiments.

\begin{tabular}{ccc}
\hline $\begin{array}{c}\text { Field } \\
\text { experiment }\end{array}$ & $\begin{array}{c}\delta^{18} \mathrm{O}_{\mathrm{H}_{2} \mathrm{O}}(\% \text { vs. } \\
\text { VSMOW) }\end{array}$ & $\begin{array}{c}\text { Final } \delta^{18} \mathrm{O}_{\mathrm{NO}_{3}}(\% \text { Vs. } \\
\text { VSMOW) }\end{array}$ \\
\hline 7 & $-1.5 \pm 0.5$ & $+0.5 \pm 0.4$ \\
& & $+1.3 \pm 0.3$ \\
8 & $-1.8 \pm 0.2$ & $-0.3 \pm 0.2$ \\
& & $-0.7 \pm 0.2$ \\
9 & $-2.2 \pm 0.2$ & $-0.1 \pm 0.2$ \\
10 & $-0.1 \pm 0.3$ & $+2.7 \pm 0.4$ \\
& $0.0 \pm 0.5$ & $+0.6 \pm 0.2$ \\
13 & $+0.2 \pm 0.2$ & $+0.1 \pm 0.2$ \\
& $+0.5 \pm 0.2$ & $+3.5 \pm 0.5$ \\
& & $+5.2 \pm 0.6$ \\
\hline
\end{tabular}

of exchange. Laboratory coculture experiments (average $+3.9 \% \pm \pm 0.8 \%$ ) were significantly lower than field experiments (average $+8.2 \% 0 \pm 1.7 \%$ ) $(p=0.0005)$. Based on these intercepts, and assuming constant $\delta^{18} \mathrm{O}_{\mathrm{O}_{2}}$ values of $+24.2 \%$ in all experiments, the combined incorporation isotope effects for ammonia oxidation $\left({ }^{18} \varepsilon_{\mathrm{k}, \mathrm{O}_{2}}+{ }^{18} \varepsilon_{\mathrm{k}, \mathrm{H}_{2} \mathrm{O}, 1}\right)$ ranged from $+11.4 \%$ to $+22.7 \%$ (Table 3 ). The isotope effect for $\mathrm{O}$ atom incorporation was very consistent among the AOB experiments $(+21.4 \% 0 \pm 1.0 \%)$ and slightly lower in AOA experiments $(+16.4 \%$ $\pm 0.6 \%$; Table 3$)$. Unfortunately, we cannot perform a statistical test between $\mathrm{AOB}$ and AOA experiments because there was only one AOA experiment in which ${ }^{18} \varepsilon_{\mathrm{k}, \mathrm{O}_{2}}+{ }^{18} \varepsilon_{\mathrm{k}, \mathrm{H}_{2} \mathrm{O}, 1}$ was measured. This combined isotope effect was measured in three field experiments (FEs 9, 10,11) and showed a range of $+11.4 \%$. $0.1 \%$ to $+20.3 \%$ o $\pm 3.1 \%$. The low value was determined to be an outlier by Chauvenet's criterion, which is defined by the value being greater than two standard deviations from the mean (Taylor 1997). After excluding this value there is no significant difference in the ${ }^{18} \varepsilon_{\mathrm{k}, \mathrm{O}_{2}}+{ }^{18} \varepsilon_{\mathrm{k}, \mathrm{H}_{2} \mathrm{O}, 1}$ measured in coculture vs. field experiments $(p=0.18)$, and the overall average is $+20.4 \%$ $\pm 2.3 \%$. This indicates that the main cause for the higher $\delta^{18} \mathrm{O}_{\mathrm{NO}_{2}}$ intercepts in field experiments compared with coculture experiments is more exchange (a larger $x_{\mathrm{AO}}$ ), not lower ${ }^{18} \varepsilon_{\mathrm{k}, \mathrm{O}_{2}}+{ }^{18} \varepsilon_{\mathrm{k}, \mathrm{H}_{2} \mathrm{O}, 1}$ values. In FE 12 there was full exchange, thus erasing any record of ${ }^{18} \varepsilon_{\mathrm{k}, \mathrm{O}}+$ ${ }^{18} \varepsilon_{\mathrm{k}, \mathrm{H}_{2} \mathrm{O}, 1}$. In FE 13 nitrite concentrations were too low for $\delta^{18} \mathrm{O}_{\mathrm{NO}_{2}}$ analyses.

The intercepts for $\delta^{18} \mathrm{O}_{\mathrm{NO}_{3}}$ in the nine complete experiments ranged from $-1.5 \%$ to $5.2 \%$ (Table 3 ). Excluding one Vineyard Sound experiment (FE 9), which was determined to be an outlier (greater than two standard deviations from the mean), lowers the upper estimate to $+1.3 \%$. With the slope and intercept from the $\delta^{18} \mathrm{O}_{\mathrm{NO}_{3}}$ regression and the isotope effects for $\mathrm{H}_{2} \mathrm{O}$ and $\mathrm{O}_{2}$ incorporation from the $\delta^{18} \mathrm{O}_{\mathrm{NO}_{2}}$ data (Fig. 5a; Table 3), the isotope effect for $\mathrm{H}_{2} \mathrm{O}$ incorporation during nitrite oxidation $\left({ }^{18} \varepsilon_{\mathrm{k}, \mathrm{H}_{2} \mathrm{O}, 2}\right)$ could be calculated using Eq. 3 . These values ranged from +0.8 to $+27.2 \%$ (Table 3 ). Laboratory experiments, all conducted with $N$. mobilis, gave ${ }^{18} \varepsilon_{\mathrm{k}, \mathrm{H}_{2} \mathrm{O}, 2}$ values ranging from $+5.8 \%$ o to $+12.4 \%$, with an average of $+8.6 \% \pm 2.3 \%$, which is lower than what was reported previously from monoculture incubations $(+17.8 \%$ \pm 4.7\%; Buchwald and Casciotti 2010). The current experiments were not shaken, though, and some of the variability observed here may be due to variable amounts of dissolved oxygen consumption, leading to variations in $\delta^{18} \mathrm{O}_{\mathrm{O}_{2}}$, which would be erroneously attributed to variations in ${ }^{18} \varepsilon_{\mathrm{k}, \mathrm{H}_{2} \mathrm{O}, 2}$. Field experiments fell at the two extremes, with FE 9 having a ${ }^{18} \varepsilon_{\mathrm{k}, \mathrm{H}_{2} \mathrm{O}, 2}$ value of $+0.8 \%$ and $\mathrm{FE} 10$ having a ${ }^{18} \varepsilon_{\mathrm{k}, \mathrm{H}_{2} \mathrm{O}, 2}$ value of $+27.2 \%$ (Table 3 ). Even for a biological process, this range in ${ }^{18} \varepsilon_{\mathrm{k}, \mathrm{H}_{2} \mathrm{O}, 2}$ is wider than expected and could represent the activity of different nitrite oxidizer communities in Vineyard Sound, Massachusetts, compared with the Costa Rica Dome.

Among the five field experiments, two (FEs 7 and 8) did not have varied $\delta^{18} \mathrm{O}_{\mathrm{H}_{2} \mathrm{O}}$, so $x_{\mathrm{AO}}$ and incorporation isotope effects could not be determined. Nevertheless, the final $\delta^{18} \mathrm{O}_{\mathrm{NO}_{3}}$ values of nitrate produced in these experiments (corrected for the preexisting nitrate) provide an independent estimate of the $\delta^{18} \mathrm{O}_{\mathrm{NO}_{3}}$ value produced via nitrification by natural marine assemblages at natural seawater $\mathrm{pH}$ and $\delta^{18} \mathrm{O}_{\mathrm{H}_{2} \mathrm{O}}$ values. The $\delta^{18} \mathrm{O}_{\mathrm{NO}_{3}}$ values produced in these experiments were between $-0.7 \%$ and $+1.3 \%$, with $\delta^{18} \mathrm{O}_{\mathrm{H}_{2} \mathrm{O}}$ values of $-1.5 \%$ and $-1.8 \%$, respectively (Table 4). These values are similar to the $\delta^{18} \mathrm{O}_{\mathrm{NO}_{3}}$ intercepts observed in experiments with variable $\delta^{18} \mathrm{O}_{\mathrm{H}_{2} \mathrm{O}}$ media. Because the $\delta^{18} \mathrm{O}_{\mathrm{H}_{2} \mathrm{O}}$ values in most of these experiments were lower than bulk seawater $\delta^{18} \mathrm{O}_{\mathrm{H}_{2} \mathrm{O}}$, the $\delta^{18} \mathrm{O}_{\mathrm{NO}_{3}}$ values from these experiments should generally be lower than the intercepts in Table $3\left(\delta^{18} \mathrm{O}_{\mathrm{NO}_{3}}\right.$ at $\delta^{18} \mathrm{O}_{\mathrm{H}_{2} \mathrm{O}}=0 \%$; produced $\delta^{18} \mathrm{O}_{\mathrm{NO}_{3}}$ should increase by $0.67-1 \%$ per $1 \%$ increase in $\delta^{18} \mathrm{O}_{\mathrm{H}_{2} \mathrm{O}}$, depending on the amount of exchange that occurred). In the last experiment (FE 13) the $\delta^{18} \mathrm{O}_{\mathrm{H}_{2} \mathrm{O}}$ values were higher $(0.2 \%$ and $0.5 \%)$ than bulk seawater, and therefore the $\delta^{18} \mathrm{O}_{\mathrm{NO}_{3}}$ values are higher than the intercept given in Table 3.

\section{Discussion}

Nitrite accumulation and oxygen isotope exchange in the ocean-Our current estimates from coculture experiments, including those with $\mathrm{AOA}$, indicate that biological equilibration between nitrite and $\mathrm{H}_{2} \mathrm{O}$ during ammonia oxidation is most likely less than $25 \%$ and that the biological equilibration between nitrite and $\mathrm{H}_{2} \mathrm{O}$ during nitrite oxidation is negligible. Field experiments generally showed higher levels of exchange (22-100\%), which we attribute to abiotic processes that occur when nitrite accumulates in seawater. Although field experiments may not exhibit some biases of culture work, we suspect that the addition of $\mathrm{NH}_{4}{ }^{+}$, which was necessary to create a measurable signal in $\delta^{18} \mathrm{O}_{\mathrm{NO}_{3}}$, perturbed the system into an unnatural state. Given the long containment in bottles, large accumulations of nitrite, and long lags before commencement of nitrite oxidation, we argue that the high exchange observed in field experiments most likely does not resemble the tightly coupled nitrification system occurring in much of the ocean.

Even in the coculture experiments the low levels of exchange could potentially be explained by abiotic, rather than biological, exchange. The rate of abiotic exchange is dependent on $\mathrm{pH}$ and temperature, and based on typical exchange rates at a seawater $\mathrm{pH}$ at room temperature (Casciotti et al. 2007; C. Buchwald and K. L. Casciotti 
unpubl.) we would expect about $2 \%$ abiotic exchange per day in our experiments. With little biological exchange occurring during ammonia oxidation and nitrite oxidation, any exchange during nitrification in the ocean may be determined strictly by duration of nitrite accumulation relative to the rate of abiotic processes. If nitrite is allowed to accumulate, exchange may be extensive, while if nitrite is kept at low levels exchange may be minimal. This observation mirrors results from Snider et al. (2010), where large amounts of nitrite accumulated during nitrification in incubations of terrestrial and agricultural soils and they measured high amounts of exchange (up to $88 \%$ ).

While most of the ocean contains very little accumulated nitrite, ammonia and nitrite oxidation can become uncoupled in the primary nitrite maximum (PNM; Wada and Hattori 1971), a region of locally elevated nitrite concentrations that frequently occurs at the base of the euphotic zone (Lomas and Lipschultz 2006). Within the PNM, nitrite oxidation rates can be quite low, and nitrite may have long residence times, on the order of weeks to months (Dore and Karl 1996; C. Buchwald and K. L. Casciotti unpubl.). Under these conditions, abiotic exchange between nitrite and $\mathrm{H}_{2} \mathrm{O}$ could be extensive, and much of the nitrate produced may have lost its primary $\delta^{18} \mathrm{O}_{\mathrm{O}_{2}}$ signal. Below the PNM, nitrite is generally held in low concentrations, with ammonia and nitrite oxidation tightly coupled. Under these circumstances, little abiotic exchange would be expected.

In addition to the PNM, a secondary nitrite maximum (SNM) occurs in areas of the ocean with low oxygen concentrations in intermediate waters, referred to as oxygen deficient zones (ODZs). The three major ODZs are located in the Eastern Tropical South Pacific, Eastern Tropical North Pacific, and the Arabian Sea. While they account for a small area of the ocean, they can have high nitrite concentrations (Codispoti et al. 1986) and a large effect on the oceanic nitrate isotope budget (Brandes and Devol 2002; Deutsch et al. 2004; Sigman et al. 2009). Nitrification can also occur at the edges of an ODZ, where nitrite and oxygen coexist (Anderson et al. 1982; Ward et al. 1989; Casciotti and McIlvin 2007). Here, too, the oxidized nitrite may have been strongly affected by equilibration. Depending on whether the majority of nitrification is associated with features such as the PNM and SNM, or in parts of the water column with tightly coupled ammonia and nitrite oxidation, oxygen isotope exchange may be more or less important in setting $\delta^{18} \mathrm{O}_{\mathrm{NO}_{3}}$ values in the ocean.

Consistency with oceanographic data and models-Relatively small vertical and horizontal gradients have been observed in intermediate and deep ocean $\delta^{18} \mathrm{O}_{\mathrm{NO}_{3}}$ values (Casciotti et al. 2002; Sigman et al. 2009), and studies interpreting $\delta^{18} \mathrm{O}_{\mathrm{NO}_{3}}$ and $\delta^{15} \mathrm{~N}_{\mathrm{NO}_{3}}$ values using biogeochemical models have generally assumed $\delta^{18} \mathrm{O}_{\mathrm{NO}_{3}}$ values of newly produced nitrate to be near that of seawater $(0 \% \pm \pm$ 1\%; Sigman et al. 2005; Casciotti and McIlvin 2007; Wankel et al. 2007). This assumption has been justified by the importance of $\mathrm{H}_{2} \mathrm{O}$ as an $\mathrm{O}$ atom source to nitrate (Andersson and Hooper 1983; Kumar et al. 1983), from high levels of equilibration between nitrite and $\mathrm{H}_{2} \mathrm{O}$ reported in early studies of ammonia oxidation (Dua et al. 1979; Andersson et al. 1982), and the low $\delta^{18} \mathrm{O}_{\mathrm{NO}_{3}}$ variations in deep water noted above. However, while equilibration of nitrite with $\mathrm{H}_{2} \mathrm{O}$ should indeed remove $\delta^{18} \mathrm{O}_{\mathrm{NO}_{3}}$ variations associated with variations in $\delta^{18} \mathrm{O}_{\mathrm{O}_{2}}$ and lessen deep ocean gradients in $\delta^{18} \mathrm{O}_{\mathrm{NO}_{3}}$ (Sigman et al. 2009), the equilibrium isotope effect $\left({ }^{18} \varepsilon_{\mathrm{eq}}\right)$ for this exchange should raise $\delta^{18} \mathrm{O}_{\mathrm{NO}_{2}}$ to $+11.4 \%$ to $+15.1 \%$ above that of ambient $\delta^{18} \mathrm{O}_{\mathrm{H}_{2} \mathrm{O}}$, depending on temperature (Casciotti et al. 2007; C. Buchwald and K. L. Casciotti unpubl.). In order to generate $\delta^{18} \mathrm{O}_{\mathrm{NO}_{3}}$ values in newly produced nitrate that are near $0 \%$, the increase in $\delta^{18} \mathrm{O}_{\mathrm{NO}_{2}}$ due to equilibration between nitrite and $\mathrm{H}_{2} \mathrm{O}$ must be offset by the kinetic isotope effect for $\mathrm{O}$ incorporation from $\mathrm{H}_{2} \mathrm{O}$ during nitrite oxidation $\left({ }^{18} \varepsilon_{\mathrm{k}, \mathrm{H}_{2} \mathrm{O}, 2}\right)$. Our results have shown that this can happen. For example, in this study, we find $\delta^{18} \mathrm{O}_{\mathrm{NO}_{3}}$ produced at values of $-0.7 \%$ to $+1.3 \%$, even where large amounts of exchange have taken place. In one of these cases, the estimated ${ }^{18} \varepsilon_{\mathrm{k}, \mathrm{H}_{2} \mathrm{O}, 2}$ value was as high as $+27.2 \%$ (Table 3 ). It is not known what may cause variation in expressed ${ }^{18} \varepsilon_{\mathrm{k}, \mathrm{H}_{2} \mathrm{O}, 2}$ values at different field sites, but it may be related to the presence of specific nitriteoxidizing bacteria or changes in their growth conditions.

The results of this study suggest that nitrification in much of the ocean may proceed with little biologically catalyzed exchange but that abiotic equilibration may be important when nitrification occurs in the vicinity of a primary or secondary nitrite maximum. Where nitrification occurs with tightly coupled ammonia and nitrite oxidation, $\mathrm{O}$ from dissolved $\mathrm{O}_{2}$ may be retained as 1 in $3 \mathrm{O}$ atoms in nitrate. This conclusion is in apparent discrepancy with models that are able to simulate the low variation in deep and intermediate ocean $\delta^{18} \mathrm{O}_{\mathrm{NO}_{3}}$ only with very little retention of $\mathrm{O}$ from dissolved oxygen $\left(x_{\mathrm{AO}} \sim 1\right)$ (Sigman et al. 2009).

In order to test the predicted $\delta^{18} \mathrm{O}_{\mathrm{NO}_{3}}$ dependence on $\delta^{18} \mathrm{O}_{\mathrm{O}_{2}}$, we constructed a simple Rayleigh model where nitrate is produced by nitrification with no biotic or abiotic exchange, so that it contains 1 in $3 \mathrm{O}$ atoms from dissolved $\mathrm{O}_{2}$ (Fig. 6). Consumption of $\mathrm{O}_{2}$ causes $\delta^{18} \mathrm{O}_{\mathrm{O}_{2}}$ to increase with an isotope effect of $18 \%$ (Bender 1990), and nitrate accumulates from that produced instantaneously at increasing $\delta^{18} \mathrm{O}_{\mathrm{O}_{2}}$ values, according to Eq. 4. According to this calculation, while $\delta^{18} \mathrm{O}_{\mathrm{O}_{2}}$ increases nearly $11.8 \%$, $\delta^{18} \mathrm{O}_{\mathrm{NO}_{3}}$ increases only $1.8 \%$, which is approximately $15 \%$ of the increase in $\delta^{18} \mathrm{O}_{\mathrm{O}_{2}}$. In addition to this, only nitrate that is locally produced should track increases in ambient $\delta^{18} \mathrm{O}_{\mathrm{O}_{2}}$, and the presence of preformed nitrate will decouple the relationship between $\delta^{18} \mathrm{O}_{\mathrm{O}_{2}}$ and $\delta^{18} \mathrm{O}_{\mathrm{NO}_{3}}$. The relationship between $\delta^{18} \mathrm{O}_{\mathrm{O}_{2}}$ and $\delta^{18} \mathrm{O}_{\mathrm{NO}_{3}}$ can also change at extremely low dissolved oxygen concentrations (high $\delta^{18} \mathrm{O}_{\mathrm{O}_{2}}$ values), where $\delta^{18} \mathrm{O}_{\mathrm{NO}_{3}}$ is elevated because of other processes, such as denitrification. It is difficult to disentangle the effects of nitrification with elevated $\delta^{18} \mathrm{O}_{\mathrm{O}_{2}}$ levels, abiotic exchange, and denitrification on $\delta^{18} \mathrm{O}_{\mathrm{NO}_{3}}$ in the vicinity of oxygen deficient zones, and more sophisticated models would be required to better evaluate the implications of these processes for deep ocean $\delta^{18} \mathrm{O}_{\mathrm{NO}_{3}}$. While we cannot exclude exchange, particularly from abiotic processes, as a factor in $\delta^{18} \mathrm{O}_{\mathrm{NO}_{3}}$ in the ocean, full exchange 


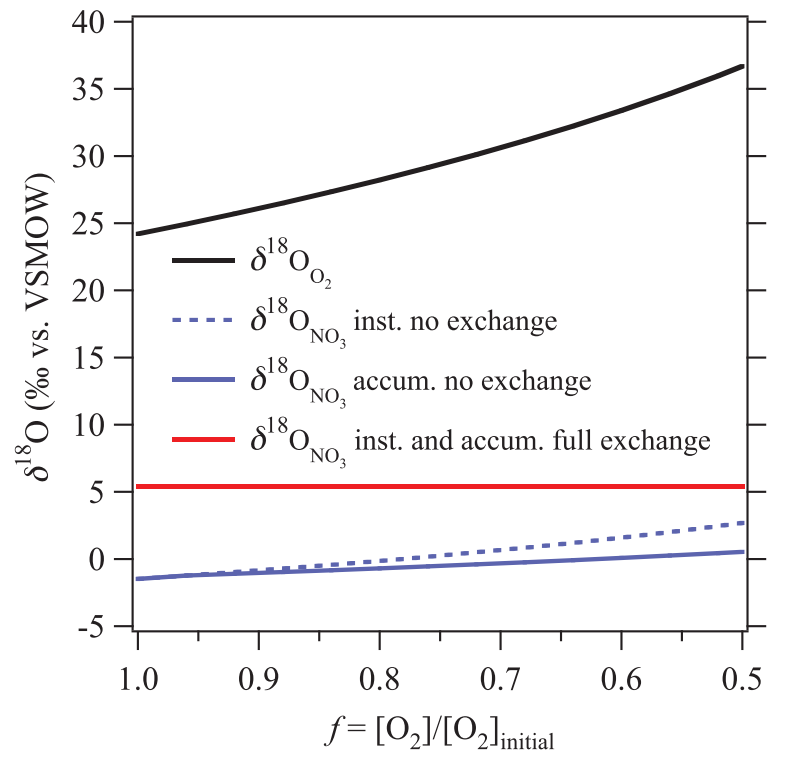

Fig. 6. Rayleigh model for nitrate production in the ocean as $\delta^{18} \mathrm{O}_{\mathrm{O}_{2}}$ increases from respiration with an isotope effect of $18 \%$. Instantaneous nitrate is produced through Eq. 4 with $\delta^{18} \mathrm{O}_{\mathrm{H}_{2} \mathrm{O}}=$ $0 \%{ }^{18} \varepsilon_{\mathrm{k}, \mathrm{O}_{2}}+{ }^{18} \varepsilon_{\mathrm{k}, \mathrm{H}_{2} \mathrm{O}, 1}=19.7 \%$ o, ${ }^{18} \varepsilon_{\mathrm{k}, \mathrm{H}_{2} \mathrm{O}, 2}=8.9 \%$, and ${ }^{18} \varepsilon_{\mathrm{eq}}=$ $12.5 \%$ with $x_{\mathrm{AO}}=0$ (dashed purple line) and $x_{\mathrm{AO}}=1$ (red line). Accumulated nitrate is summed from the incremental products and their $\delta^{18} \mathrm{O}$ values with $x_{\mathrm{AO}}=0$ (solid purple line). For $x_{\mathrm{AO}}=$ 1 the $\delta^{18} \mathrm{O}_{\mathrm{NO}_{3}}$ values are the same for accumulated and instantaneous nitrate.

may not be necessary to explain the small gradients observed in intermediate and deep $\delta^{18} \mathrm{O}_{\mathrm{NO}_{3}}$ values.

Expected $\delta^{18} \mathrm{O}_{\mathrm{NO}_{3}}$ for nitrification in the oceanThe $\delta^{18} \mathrm{O}$ value of newly produced nitrate from nitrification $\left(\delta^{18} \mathrm{O}_{\mathrm{NO}_{3}, \text { nit }}\right)$ is an important parameter for biogeochemical models used to interpret oceanic $\delta^{18} \mathrm{O}_{\mathrm{NO}_{3}}$ and $\delta^{15} \mathrm{~N}_{\mathrm{NO}_{3}}$ (Wankel et al. 2007; DiFiore et al. 2009; Sigman et al. 2009). This value is constrained to be less than $+2.5 \%$ (the average $\delta^{18} \mathrm{O}$ value of deep ocean nitrate; Casciotti et al. 2002; Knapp et al. 2008; DiFiore et al. 2009) because processes consuming nitrate should cause ${ }^{18} \mathrm{O}$ enrichment in residual nitrate relative to the nitrification source (Granger et al., 2004; Granger et al., 2008). The main goal of this study was to develop a better understanding of the determinants of $\delta^{18} \mathrm{O}_{\mathrm{NO}_{3} \text {, nit }}$ to use in global ocean nitrate isotope models. Previous experiments with ammoniaoxidizing bacteria and nitrite-oxidizing bacteria grown separately suggested that the $\delta^{18} \mathrm{O}_{\mathrm{NO}_{3}}$ values for nitrate produced in well-oxygenated seawater $\left(\delta^{18} \mathrm{O}_{\mathrm{H}_{2} \mathrm{O}} \sim 0 \%\right.$, $\delta^{18} \mathrm{O}_{\mathrm{O}_{2}} \sim+23.5 \%$ ) could range from $-8.3 \%$ o to $-0.7 \%$, depending on amounts of exchange and fractionation associated with the different species investigated (Buchwald and Casciotti 2010). However, the extent to which variations in $\delta^{18} \mathrm{O}_{\mathrm{H}_{2} \mathrm{O}}$ and $\delta^{18} \mathrm{O}_{\mathrm{O}_{2}}$ would affect $\delta^{18} \mathrm{O}_{\mathrm{NO}_{3} \text {,nit }}$ in mixed communities was not well constrained. In our current coculture experiments, where very little nitrite accumulated (and consequently a low amount of exchange was observed), $\delta^{18} \mathrm{O}_{\mathrm{NO}_{3}}$ values ranged from $-1.5 \%$ to $+0.7 \%$, with an average of $-0.9 \%$ $\pm 0.8 \%$. In the field experiments we measured slightly larger $\delta^{18} \mathrm{O}_{\mathrm{NO}_{3}}$ intercepts, falling between $-0.7 \%$ and $1.3 \%$ (neglecting one outlier; Table 4).

One of the main factors driving variations in $\delta^{18} \mathrm{O}_{\mathrm{NO}_{3}}$ produced in our experiments appeared to be the duration of nitrite accumulation and the extent to which abiotic exchange altered the $\delta^{18} \mathrm{O}_{\mathrm{NO}_{2}}$ value prior to oxidation. When ammonia oxidation outpaced nitrite oxidation and nitrite accumulated, significant amounts of abiotic exchange between nitrite and $\mathrm{H}_{2} \mathrm{O}$ could take place, generally leading to higher $\delta^{18} \mathrm{O}_{\mathrm{NO}_{3}}$ values. This may be counterintuitive because $\delta^{18} \mathrm{O}_{\mathrm{O}_{2}}$ is always higher than $\delta^{18} \mathrm{O}_{\mathrm{H}_{2} \mathrm{O}}$ in the ocean. However, there is a large kinetic isotope effect for $\mathrm{O}$ incorporation, which lowers the overall $\delta^{18} \mathrm{O}$ value of the incorporated $\mathrm{O}$ atom. Exchange leads to higher $\delta^{18} \mathrm{O}_{\mathrm{NO}_{3}}$ values because of the equilibrium isotope effect for exchange between nitrite and $\mathrm{H}_{2} \mathrm{O}$. In one field experiment from the CRD (FE 10), the $\delta^{18} \mathrm{O}_{\mathrm{NO}_{3}}$ value was similar $(-0.7 \%$ $\pm 1.6 \%)$ to coculture data, despite the higher amounts of exchange observed. This is potentially explained by a large isotope effect for $\mathrm{H}_{2} \mathrm{O}$ incorporation during nitrite oxidation $\left({ }^{18} \varepsilon_{\mathrm{k}, \mathrm{H}_{2} \mathrm{O}, 2}\right)$, which offsets the equilibrium isotope effect. In another case (FE 13) we observed high levels of exchange despite low nitrite accumulations. This highlights the possibility that it is not necessarily the amount of nitrite that accumulates, but rather the duration of nitrite accumulation or rate of biological turnover relative to the rate of abiotic equilibration, that determines the effect of abiotic exchange on $\delta^{18} \mathrm{O}_{\mathrm{NO}_{3}}$.

The anomalous Vineyard Sound experiment (FE 9) had a $\delta^{18} \mathrm{O}_{\mathrm{NO}_{3}}$ intercept that was determined to be an outlier among all other experiments, although the $\delta^{18} \mathrm{O}_{\mathrm{NO}_{2}}$ intercept was not. This combination of $\delta^{18} \mathrm{O}_{\mathrm{NO}_{2}}$ and $\delta^{18} \mathrm{O}_{\mathrm{NO}_{3}}$ intercepts yielded a low estimate of ${ }^{18} \varepsilon_{\mathrm{k}, \mathrm{H}_{2} \mathrm{O}, 2}$ from Eq. 4. We do not have an explanation for why this experiment is so different from the others, but given the extremely long duration of nitrite accumulation, we do not believe the results to be representative of nitrification in the open ocean. A $\delta^{18} \mathrm{O}_{\mathrm{NO}_{3}}$ value of $5.3 \%$ is also not consistent with deep ocean $\delta^{18} \mathrm{O}_{\mathrm{NO}_{3}}$ values of $2.5 \%$ or less, although we cannot rule out the possibility that nitrification in the euphotic zone produces nitrate with a higher $\delta^{18} \mathrm{O}_{\mathrm{NO}_{3}}$ value.

Despite large ranges in measured exchange and incorporation isotope effects, there was remarkably little variation in $\delta^{18} \mathrm{O}_{\mathrm{NO}_{3}}$ produced. The current results suggest that $\delta^{18} \mathrm{O}_{\mathrm{NO}_{3}}$ of newly produced nitrate in the ocean (when $\delta^{18} \mathrm{O}_{\mathrm{H}_{2} \mathrm{O}}=0 \%$ and $\delta^{18} \mathrm{O}_{\mathrm{O}_{2}}=+24.2 \%$ ) most likely lies between $-1.5 \%$ and $+1.3 \%$. This range represents differences in microbial communities and growth conditions under which nitrate is produced, which may lead to different amounts of exchange and/or fractionation during ammonia and nitrite oxidation. The full range in $\delta^{18} \mathrm{O}_{\mathrm{NO}_{3}}$ values produced in the ocean may be slightly larger as a result of variations in $\delta^{18} \mathrm{O}_{\mathrm{H}_{2} \mathrm{O}}$ and $\delta^{18} \mathrm{O}_{\mathrm{O}_{2}}$ values in seawater. Variations in $\delta^{18} \mathrm{O}_{\mathrm{NO}_{3}}$, nit due to $\delta^{18} \mathrm{O}_{\mathrm{O}_{2}}$ variations are likely to be less than $4 \% 0(1 / 3 \times$ variation in $\delta^{18} \mathrm{O}_{\mathrm{O}_{2}}$ ), and those due to $\delta^{18} \mathrm{O}_{\mathrm{H}_{2} \mathrm{O}}$ are likely to be smaller than that $\left(2 / 3 \times\right.$ variation in $\left.\delta^{18} \mathrm{O}_{\mathrm{H}_{2} \mathrm{O}}\right)$. While there may be slight variations in the $\delta^{18} \mathrm{O}_{\mathrm{NO}_{3}}$ produced by nitrification 
in the ocean, the overall predicted range is narrow, and the better constrained relationship between $\delta^{18} \mathrm{O}_{\mathrm{NO}_{3} \text {,nit }}$, $\delta^{18} \mathrm{O}_{\mathrm{H}_{2} \mathrm{O}}$, and $\delta^{18} \mathrm{O}_{\mathrm{O}_{2}}$ can be used in future oceanic models.

\section{Acknowledgments}

We thank Frederica Valois and John Waterbury for generously providing the ammonia-oxidizing and nitrite-oxidizing bacteria used in this study. We are grateful to Mike Landry (Chief Scientist in Costa Rica), Doug Capone and Will Berelson (co-Chief Scientists in the South Pacific), and the Captain and Crew of the R/V Melville for enabling the collection of the samples. We would also like to thank Meredith White for help with the statistical analysis in this study, D. Sigman for helpful discussions, and two anonymous reviewers for their thorough and constructive comments. This research was funded by the National Science Foundation Chemical Oceanography grants 05-26277 and 09610998 to K.L.C.

\section{References}

Altabet, M. 2007. Constraints on the oceanic N balance/ imbalance from sedimentary ${ }^{15} \mathrm{~N}$ records. Biogeoscience 4: 75-86, doi:10.5194/bg-4-75-2007

Anderson, J. J., A. Okubo, A. S. Robbins, and F. A. Richards. 1982. A model for nitrate distributions in oceanic minimum zones. Deep Sea Res. 29: 1113-1140, doi:10.1016/ 0198-0149(82)90031-0

Andersson, K. K., S. B. Philson, and A. B. Hooper. 1982. ${ }^{18}$ O isotope shift in ${ }^{15} \mathrm{~N}$ NMR analysis of biological N-oxidations: $\mathrm{H}_{2} \mathrm{O}-\mathrm{NO}_{2}^{-}$exchange in the ammonia-oxidizing bacterium Nitrosomonas. Proc. Natl. Acad. Sci. USA 79: 5871-5875, doi:10.1073/pnas.79.19.5871

- AND A. B. Hooper. 1983. $\mathrm{O}_{2}$ and $\mathrm{H}_{2} \mathrm{O}$ are each the source of one $\mathrm{O}$ in $\mathrm{NO}_{2}^{-}$produced from $\mathrm{NH}_{3}$ by Nitrosomonas: 15N-NMR evidence. FEBS Lett. 164: 236-240, doi:10.1016/ 0014-5793(83)80292-0

Balch, W. E., G. E. Fox, L. J. Magrum, C. R. Woese, and R. S. Wolfe. 1979. Methanogens-re-evaluation of a unique biological group. Microbiol. Rev. 43: 260-296.

Bender, M. L. 1990. The $\delta^{18} \mathrm{O}$ of dissolved $\mathrm{O}_{2}$ in seawater-a unique tracer of circulation and respiration in the deep-sea. $\mathrm{J}$. Geophys. Res. Oceans 95: 22243-22252, doi:10.1029/ JC095iC12p22243

Böhlke, J. K., S. J. Mroczkowski, and T. B. Coplen. 2003. Oxygen isotopes in nitrate: New reference materials for O-18:O-17:O-16 measurements and observations on the nitrate-water equilibration. Rapid Commun. Mass Spectrom. 17: 1835-1846, doi:10.1002/rcm.1123

Brandes, J. A., And A. H. Devol. 2002. A global marine-fixed nitrogen isotopic budget: Implications for Holocene nitrogen cycling. Glob. Biochem. Cycles 16: 1-14.

Buchwald, C., And K. L. CAsciotti. 2010. Oxygen isotopic fractionation and exchange during bacterial nitrite oxidation. Limnol. Oceanogr. 55: 1064-1074, doi:10.4319/lo.2010.55.3. 1064

Casciotti, K. L., J. K. Böhlke, M. R. McIlvin, S. J. Mroczkwski, and J. E. Hannon. 2007. Oxygen isotopes in nitrite: Analysis, calibration and equilibration. Anal. Chem. 79: 2427-2436, doi:10.1021/ac061598h

, C. Buchwald, A. E. Santoro, and C. Frame. 2011. Assessment of nitrogen and oxygen isotopic fractionation during nitrification and its expression in the marine environment. Methods Enzymol. 486: 253-275, doi:10.1016/ S0076-6879(11)86011-8
, AND M. R. McIlvin. 2007. Isotopic analyses of nitrate and nitrite from reference mixtures and application to eastern tropical North Pacific waters. Mar. Chem. 107: 184-201, doi:10.1016/j.marchem.2007.06.021

- AND C. BuCHWALD. 2010. Oxygen isotopic exchange and fractionation during bacterial ammonia oxidation. Limnol. Oceanogr. 55: 753-762, doi:10.4319/ lo.2009.55.2.0753

, D. M. Sigman, G. H. Hastings, J. K. Böhlke, and A. Hilkert. 2002. Measurement of the oxygen isotopic composition of nitrate in seawater and freshwater using the denitrifier method. Anal. Chem. 74: 4905-4912, doi:10.1021/ ac020113w

Codispoti, L. A., J. A. Brandes, J. P. Christensen, A. H. Devol, S. W. A. Naqvi, H. W. Paerl, and T. Yoshinari. 2001. The oceanic fixed nitrogen and nitrous oxide budgets: Moving targets as we enter the anthropocene? Sci. Mar. 65: 85-102, doi: $10.3989 /$ scimar.2001.65s 285

_ AND OTHERS. 1986. High nitrite levels off Northern Peru: A signal of instability in the marine denitrification rate. Science 233: 1200-1202, doi:10.1126/science.233.4769.1200

Cox, R. D. 1980. Development of analytical methodologies for parts per billion level determination of nitrate, nitrite and $\mathrm{N}$ Nitroso group content. Ph.D. thesis. Univ. of Iowa.

Deutsch, C., D. M. Sigman, R. C. Thunell, A. N. Meckler, and G. H. HAug. 2004. Isotopic constraints on glacial/interglacial changes in the oceanic nitrogen budget. Glob. Biogeochem. Cycles 18: GB4012, doi:10.1029/2003GB002189

DiFiore, P. J., D. M. Sigman, and R. B. Dunbar. 2009. Upper ocean nitrogen fluxes in the Polar Antarctic Zone: Constraints from the nitrogen and oxygen isotopes of nitrate. Geochem. Geophys. Geosys. 10: Q11016, doi:10.1029/2009GC002468

DiSpirito, A. A., AND A. B. Hooper. 1986. Oxygen-exchange between nitrate molecules during nitrite oxidation by Nitrobacter. J. Biol. Chem. 261: 10534-10537.

Dore, J. E., AND D. M. KARL. 1996. Nitrification in the euphotic zone as a source of nitrite, nitrate and nitrous oxide at Station ALOHA. Limnol. Oceanogr. 41: 1619-1628, doi:10.4319/ lo.1996.41.8.1619

Dua, R. D., B. Bhandari, and D. J. D. Nicholas. 1979. Stable isotope studies on the oxidation of ammonia to hydroxylamine by Nitrosomonas europaea. FEBS Lett. 106: 401-404, doi:10.1016/0014-5793(79)80541-4

Eppley, R. W., And B. J. Peterson. 1979. Particulate organic matter flux and planktonic new production in the deep ocean. Nature 282: 677-680, doi:10.1038/282677a0

Epstein, S., AND T. MAYedA. 1953. Variation of $\mathrm{O}^{18}$ content of waters from natural sources. Geochim. Cosmochim. Acta. 4: 213-224, doi:10.1016/0016-7037(53)90051-9

Friedman, S. H., W. Massefski, and T. C. Hollocher. 1986. Catalysis of intermolecular oxygen atom transfer by nitrite dehydrogenase of Nitrobacter agilis. J. Biol. Chem. 261: 10538-10543.

Garside, C. 1982. A chemiluminescent technique for the determination of nanomolar concentrations of nitrate and nitrite in seawater. Mar. Chem. 11: 159-167, doi:10.1016/ 0304-4203(82)90039-1

Granger, J., And D. M. Sigman. 2009. Removal of nitrite with sulfamic acid for nitrate $\mathrm{N}$ and $\mathrm{O}$ isotope analysis with the denitrifier method. Rapid Commun. Mass Spectrom. 23: 3753-3762, doi:10.1002/rcm.4307

- —, M. F. Lehmann, And P. D. Tortell. 2008. Nitrogen and oxygen isotope fractionation during dissimilatory nitrate reduction by denitrifying bacteria. Limnol. Oceanogr. 53: 2533-2545, doi:10.4319/lo.2008.53.6.2533 
J. A. Needoba, and P. J. Harrison. 2004. Coupled nitrogen and oxygen isotope fractionation of nitrate during assimilation by cultures of marine phytoplankton. Limnol. Oceanogr. 49: 1763-1773, doi:10.4319/1o.2004. 49.5.1763

Gruber, N., and J. N. Galloway. 2008. An Earth-system perspective of the global nitrogen cycle. Nature 451: 293-296, doi:10.1038/nature06592

— And J. L. SARmiento. 1997. Global patterns of marine nitrogen fixation and denitrification. Glob. Biogeochem. Cycles 11: 235-266, doi:10.1029/97GB00077

Knapp, A. N., P. J. DiFiore, C. Deutsch, D. M. Sigman, and F. LiPSCHULTZ. 2008. Nitrate isotopic composition between Bermuda and Puerto Rico Implications for $\mathrm{N}_{2}$ fixation in the Atlantic Ocean. Glob. Biogeochem. Cycles 22: GB3014, doi:10.1029/2007GB003107

Kroopnick, P. M., And H. C. Craig. 1972. Atmospheric oxygen: Isotopic composition and solubility fractionation. Science 175: 54-55, doi:10.1126/science.175.4017.54

Kumar, S., D. J. D. Nicholas, and E. H. Williams. 1983. Definitive ${ }^{15} \mathrm{~N}$ NMR evidence that water serves as a source of O during nitrite oxidation by. FEBS Lett. 152: 71-74, doi:10.1016/0014-5793(83)80484-0

Lomas, M. W., And F. Lipschultz. 2006. Forming the primary nitrite maximum: Nitrifiers or phytoplankton. Limnol. Oceanogr. 51: 2453-2467, doi:10.4319/lo.2006.51.5.2453

McIlvin, M. R., and M. A. Altabet. 2005. Chemical conversion of nitrate and nitrite to nitrous oxide and nitrogen and oxygen isotopic analysis in freshwater and seawater. Anal. Chem. 77: 5589-5595, doi:10.1021/ac050528s

- AND K. L. CAsciotti. 2006. Method for the analysis of $\delta^{18} \mathrm{O}$ in water. Anal. Chem. 78: 2377-2381, doi:10.1021/ ac051838d

- AND . 2011. Technical updates to the bacterial method for nitrate isotopic analyses. Anal. Chem. 83: 1850-1856, doi:10.1021/ac1028984

Santoro, A. E., and K. L. Casciotti. 2011. Enrichment and characterization of ammonia-oxidizing archaea from the open ocean: Phylogeny, physiology and stable isotope fractionation. Int. Soc. Microb. Ecol. J. 5: 1796-1808.

Sigman, D. M., K. L. Casciotti, M. Andreani, C. Barford, M. Galanter, And J. K. Bohlke. 2001. A bacterial method for the nitrogen isotopic analysis of nitrate in seawater and freshwater. Anal. Chem. 73: 4145-4153, doi:10.1021/ ac010088e

, J. Granger, P. J. DiFiore, M. M. Lehmann, R. Ho, G. Cane, and A. van Green. 2005. Coupled nitrogen and oxygen isotope measurements of nitrate along the eastern North Pacific margin. Glob. Biogeochem. Cycles 19: 1-14, doi:10.1029/2005GB002458
- AND OTHERs. 2009. The dual isotopes of deep nitrate as a constraint of the cycle and budget of oceanic fixed nitrogen. Deep-Sea Res. I 56: 1419-1439, doi:10.1016/j.dsr.2009.04.007

Snider, D. M., J. Spoelstra, S. L. Schiff, and J. J. VenkitesWARAN. 2010. Stable oxygen isotope ratios of nitrate produced from nitrification: ${ }^{18} \mathrm{O}$-labeled water incubations of agricultural and temperate forest soils. Environ. Sci. Technol. 44: 5358-5364, doi:10.1021/es1002567

SolorZANO, L. 1969. Determination of ammonia in natural waters by the phenolhypochlorite method. Limnol. Oceanogr. 14: 799-801, doi:10.4319/1o.1969.14.5.0799

Strickland, J. D. H., and T. R. Parsons. 1972. A practical handbook of seawater analysis. Bull. Fish. Res. Board Can. 167: $1-310$.

TAYlOR, J. R. 1997. An introduction to error analysis, 2nd ed. University Science Books.

Wada, E., AND A. Hattori. 1971. Nitrite metabolism in the euphotic layer of the central North Pacific Ocean. Limnol. Oceanogr. 16: 766-772, doi:10.4319/lo.1971.16.5.0766

Wankel, S. D., C. Kendall, J. T. Pennington, F. P. Chavez, and A. PAytan. 2007. Nitrification in the euphotic zone as evidenced by nitrate dual isotopic composition: Observations from Monterey Bay, California. Glob. Biogeochem. Cycles 21: GB2009, doi:10.1029/2006GB002723

Ward, B. B., AND A. F. CARlucci. 1985. Marine ammoniaoxidizing and nitrite oxidizing bacteria- seriological diversity determined by immunofluorescence in culture and in the environment. Appl. Environ. Microbiol. 50: 194-201.

, H. E. Glover, AND F. Lipschultz. 1989. Chemoautotrophic activity and nitrification in the oxygen minimum zone off Peru. Deep-Sea Res. 36: 1031-1051.

WATson, S. W. 1965. Characteristics of a marine nitrifying bacterium, Nitrosocystis oceanus sp. n. Limnol. Oceanogr. 10: R274-R289. - AND J. B. Waterbury. 1971. Characteristics of two marine nitrite oxidizing bacteria, Nitrospina gracilis nov. gen. nov. sp. and Nitrococcus mobilis nov. gen. nov. sp. Arch. Microbiol. 77: 203-230, doi:10.1007/BF00408114

York, D. 1966. Least-squares fitting of straight lines. Can. J. Phys. 44: 1079-1086, doi:10.1139/p66-090

- N. M. Evensen, M. L. Martinez, and J. D. B. Delgado. 2004. Unified equations for the slope, intercept, and standard errors of the best straight line. Am. J. Phys. 72: 367-375, doi:10.1119/1.1632486

Associate editor: H. Maurice Valett

Received: 05 December 2011 Accepted: 08 May 2012 Amended: 19 May 2012 